\title{
Happily Ever After: Immigration, Natives' Marriage, and Fertility
}

\section{Citation}

Carlana, Michela, and Marco Tabellini. "Happily Ever After: Immigration, Natives' Marriage and Fertility." Harvard Business School Working Paper, No. 19-004, July 2018. (IZA (Institute of Labor Economics) Discussion Paper Series, No. 11467, April 2018.J

\section{Permanent link}

http://nrs.harvard.edu/urn-3:HUL.InstRepos:37326941

\section{Terms of Use}

This article was downloaded from Harvard University's DASH repository, and is made available under the terms and conditions applicable to Open Access Policy Articles, as set forth at http:// nrs.harvard.edu/urn-3:HUL.InstRepos:dash.current.terms-of-use\#OAP

\section{Share Your Story}

The Harvard community has made this article openly available.

Please share how this access benefits you. Submit a story.

Accessibility 


\section{Happily Ever After: Immigration, Natives' Marriage, and Fertility}

Michela Carlana Marco Tabellini

Working Paper 19-004 


\title{
Happily Ever After: Immigration, Natives’ Marriage, and Fertility
}

\author{
Michela Carlana \\ Harvard Kennedy School \\ Marco Tabellini \\ Harvard Business School
}

Working Paper 19-004 


\title{
Happily Ever After: \\ Immigration, Natives' Marriage, and Fertility*
}

\author{
Michela Carlana ${ }^{\dagger}$ Marco Tabellini ${ }^{\ddagger}$
}

[This Version: July 2018]

\begin{abstract}
In this paper, we study the effects of immigration on natives' marriage, fertility, and family formation across US cities between 1910 and 1930. Instrumenting immigrants' location decision by interacting pre-existing ethnic settlements with aggregate migration flows, we find that immigration raised marriage rates, the probability of having children, and the propensity to leave the parental house for young native men and women. We show that these effects were driven by the large and positive impact of immigration on native men's employment and occupational standing, which increased the supply of "marriageable men". We also explore alternative mechanisms - changes in sex ratios, natives' cultural responses, and displacement effects of immigrants on female employment - and provide evidence that none of them can account for a quantitatively relevant fraction of our results. JEL: J12, J13, J61, N32 .
\end{abstract}

${ }^{*}$ We thank for their useful suggestions Jerome Adda, David Autor, Francesco Billari, Maristella Botticini, Nicola Gennaioli, Simon Goerlach, Ross MacMillan, Nathan Nunn, Ben Olken, Nico Voigtlaender, Heidi Williams and seminar participants of the AIEL-INPS workshop "Immigration: Challenges and Opportunities for European Policy and Politics".

${ }^{\dagger}$ Harvard Kennedy School (e-mail: michela_carlana@hks.harvard.edu).

${ }^{\ddagger}$ Harvard Business School (e-mail: mtabellini@hbs.edu). 


\section{Introduction}

Immigration has always played a key role in American history. In the past 40 years, between 1970 and 2010, the number of foreign born individuals living in the United States increased from 9 to roughly 40 million, with the share of immigrants over US population skyrocketing from 4.7 to 13 percent. ${ }^{1}$ These trends mirror a very similar pattern that took place between 1850 and 1920, a period when more than 30 million immigrants moved to the US from Europe (Figure 1). Alongside these trends, a heated debate on the economic, social, and political consequences of immigration has often emerged (Porter, 2017). A large body of the literature has investigated the effects of immigration, exploring how immigrants affect natives' wages and employment on the one hand (Card, 2001; Borjas, 2003; Borjas and Katz, 2007; Ottaviano and Peri, 2012), and political outcomes and electoral results on the other (Mayda et al., 2016; Halla et al., 2017). Somewhat surprisingly, however, much less is known about the impact of immigration on key social outcomes, such as marriage rates, fertility, and family formation among natives.

In this paper, we study the effect of the inflow of immigrants to US cities between 1910 and 1930 on marriage and on the probability of having children for young natives, and we explore the mechanisms that may drive these results. In particular, among the mediating channels, we consider changes in employment opportunities for native men induced by the immigration wave, as well as changes in sex ratios, natives' cultural responses, and displacement effects of immigrants on female employment.

At the beginning of the twentieth century, 14 percent of the US population was foreign born, due to the migration of more than 30 million Europeans since 1850 (Figure 1). After 1915, however, World War I and the Immigration Acts (1921 and 1924) put an end to the Age of Mass Migration and drastically reduced immigration to the US (Abramitzky and Boustan, 2017; Ager and Hansen, 2017). The key feature of these shocks is that they had heterogeneous effects across European countries. Since immigrants tend to cluster geographically along ethnic lines (Card, 2001; Lafortune and Tessada, 2014), variation across sending regions mechanically translates into variation in the number as well as in the mix of immigrants received by US cities over time.

Exploiting this variation, we construct a "leave-out" version of the classic shift-share instrument often adopted in the immigration literature (Altonji and Card, 1991; Card, 2001). In particular, we predict the number of immigrants to US cities in a given year by interacting the geographic variation in historical settlements of different ethnic groups

\footnotetext{
${ }^{1}$ US immigration statistics are underestimated because of the presence of large numbers of undocumented immigrants. According to some recent estimates (see Pew Center 2017), if undocumented immigrants were included, the share of foreign born over US population would be at least 4 percentage points higher (i.e. around 17 percent).
} 
with the time-series variation in national flows from each sending region, net of the individuals that eventually settled in a given city's metropolitan statistical area (MSA). ${ }^{2}$ The key identifying assumption behind the instrument is that the city-specific characteristics that attracted early movers from each ethnic group must not have a time-varying effect on local economic and social conditions in subsequent decades. ${ }^{3}$ For instance, this assumption would be violated if immigrants in 1900 settled in a given city anticipating subsequent economic growth. Below, we perform a number of checks - including testing for pre-trends and interacting year dummies with pre-migration city characteristics - to assess the validity of the instrument, and show that our results are robust to the use of alternative specifications.

Using this empirical strategy, we find that immigration increased marriage and the probability of having children for native men and women. Our estimates are economically meaningful, and suggest that a five percentage point (equivalent to a one standard deviation) increase in immigration raised natives' marriage rates and the children-to-women ratio by 2 and 3 percent respectively. When decomposing the increase in fertility between the intensive (i.e. more children per woman) and the extensive (i.e. more women having at least one child) margin, we document that the latter was quantitatively more important than the former. Specifically, our estimates imply that for every 10 new babies born from native women, 7 were due to the extensive margin, while only 3 were due to the intensive margin.

Exploiting the granularity of full count data, we explore how our main results vary depending on age and parental background. We show that the increase in both fertility and marriage was entirely driven by young couples, namely women (resp. men) aged 18-25 (resp. 20-27). Consistent with these findings, we also document that immigration induced young natives to leave their parental house earlier, and to set up an independent family unit. At the time, marriage markets were highly segmented along ethnic lines, and natives were unlikely to marry with foreign born individuals. In fact, more than $95 \%$ of U.S. born women were getting married with U.S. born men. Ethnic segmentation of marriage markets was further reinforced by the provision of Section 3 of the 1907 Expatriation Act, which mandated that native women marrying a foreign born individuals would lose their US citizenship and could get it back only when their husband was naturalized. Therefore, they were also de iure strongly disincentivized to marry an immigrant. This, in turn, allows us to isolate the effects of immigration on natives' marriage and fertility, without confounding them with mechanical changes in the relative supply of men and women in

\footnotetext{
${ }^{2}$ We focus on European immigrants (see Table A.1 in the appendix for the complete list of sending countries), but results are robust to extending the analysis to all other non-European countries.

${ }^{3}$ See also the recent paper by Goldsmith-Pinkham et al. (2018) for a formal discussion of Bartik instruments, a class of instrumental variables that also include the shift-share.
} 
the marriage market.

We provide evidence that our main results were driven by the large, positive impact of immigration on native men's employment, which increased the supply of "marriageable men" and made it easier for both men and women to marry, set up an independent household, and have kids. Specifically, our estimates suggest that for every ten new immigrants, one and a half more jobs were created for native men aged 20-35. Immigration also fostered natives' occupational standing, by inducing native workers to take up better jobs and move away from occupations more exposed to immigrants' competition, which tended to have lower skill requirements. Such large, positive effects on natives' employment were made possible by the fact that immigration increased firms' investment and productivity, in turn promoting industrialization and economic activity, and by complementarity between immigrants and natives in the labor markets (Peri and Sparber, 2009).

Next, we provide evidence that none of the alternative mechanisms can account for a quantitatively relevant fraction of our findings. First, we explore the possibility that immigration increased female marriage rates by altering sex ratios, i.e. the relative number of men and women, as more than $60 \%$ of immigrants entering the US at the time were young men (Figure A.1). In contrast with this mechanism, however, immigration induced not only native women but also native men to marry more and to have more kids, suggesting that changes in sex ratios alone cannot be driving our main results. We also provide evidence that the inflow of immigrants did not raise the probability that native women married and had kids with foreign born. We also unveil some interesting heterogeneous patterns, which depended on men's parentage. Specifically, even if immigration had on average a positive effect on marriage rates of native men, this did not happen for second generation men, who were probably more exposed to immigrants' competition in the marriage market (Angrist, 2002; Lafortune, 2013).

Second, we provide suggestive evidence that higher higher marriage rates among US born did not result from a cultural response by native couples aimed at "preserving" their own race (Bisin and Verdier, 2000; Spolaore and Wacziarg, 2016). In particular, building on the measure of linguistic distance from Chiswick and Miller (2005), we construct an index of cultural diversity, and show that the latter did not have any effect on natives' marriage rates. Lastly, we document that direct (negative) effects of immigration on female labor force participation, which might have induced women to first leave the labor force and then get married and have kids, cannot explain our key findings. Exploiting variation across age groups, we show that the decrease in labor force participation was limited to women whose marriage rates increased in response to immigration. Given the stigma attached to the work of wives outside the home at the beginning of the twentieth century, women were likely to quit their job as a consequence of marriage (Goldin, 2006). 
Our results are related to several strands of the literature. First, we complement the recent paper by Autor et al. (2018) by showing that a positive (rather than a negative) shock to employment opportunities of men increases (instead of reducing) marriage, fertility, and financial independence of young couples. Despite the difference in the historical context - early twentieth century vs contemporaneous period - and in the source of the income shock - immigration vs trade - comparing results in this paper with those in Autor et al. (2018) suggests that some key policy-relevant parameters, such as the elasticity of marriage and fertility to income, can be stable over time. At the same time, however, while our estimates on fertility are in line with those in Kearney and Wilson (2017) that studies the shock associated with "fracking booms", differently from us, the latter paper does not find a positive effect of an employment boom on marriage rates. One possible interpretation for this difference is that the cultural environment might mediate the transmission of income shocks to social outcomes.

Second, our paper is related to the vast literature on the effects of sex ratios on marriage market outcomes of men and women. Focusing on the same historical context, Angrist (2002) exploits variation in sex ratios for second generation immigrants induced by the arrival of individuals from different countries. We complement this paper by showing that immigration can impact marriage rates and fertility in receiving countries not only by altering sex ratios for second generation immigrants, but also by affecting natives' employment. Moreover, the differential effect of immigration on marriage rates of native men (positive for natives with native parents, but close to zero for second generation immigrants) is consistent with findings in Abramitzky et al. (2011), who show that in French regions where more men died during WWI, men (resp. women) were better (resp. worse) off in the marriage market. Finally, our work is related to an independent and contemporaneous paper by Ager and Hansen (2017), who study the effects of immigration on natives' marriage and find results consistent with those provided here. We complement this work by considering a more thourough set of socio-economic outcomes and by investigating the different channels at play.

Lastly, our paper contributes to the literature that explores the effect of immigration on female labor force participation and fertility. Findings in Furtado and Hock (2010) and Furtado (2016) suggest that the availability of lower cost childcare opportunities offered by the inflow of immigrants in recent decades allowed college educated women to both have more children and work longer hours, attenuating the negative correlation between childbearing and labor force participation. In our historical context, we show that the negative effect of immigration on female labor force participation was concentrated exclusively on women in the age group that experienced an increase in fertility and in marriage. Our findings are in line with the evidence provided by Goldin (1990, 2006): 
at the beginning of twentieth century, native women would quit their job upon getting married and having a child. Very often, marriage bars required firms to fire women upon marriage. Also, most women took care of their own children, and additional childbearing was assigned to black - and not immigrant - women.

The paper is structured as follows. Section 2 describes the historical background. Section 3 presents the data. Section 4 lays out our empirical strategy, constructs the instrument for immigration, and reports first stage results. Section 5 investigates the effects of immigration on natives' marriage, fertility, and propensity to leave the parental house. Section 6, explores the mechanisms. Section 7 concludes.

\section{Historical Background}

\subsection{The Age of Mass Migration}

Between 1850 and 1915, more than 30 million Europeans migrated to the United States. This massive migration episode took place in two waves: until 1890, most immigrants came from the British Isles, Germany, and Scandinavia; then, from the late 1880s, following the introduction of steam technology in shipping, which drastically reduced migration costs, immigration from Southern and Eastern Europe increased steadily (Keeling, 1999). In 1870, almost $90 \%$ of the foreign born came from Northern and Western European countries, whereas less than 5\% of immigrants had arrived from Southern and Eastern Europe (Figure 2). By 1920, however, the situation had changed dramatically, and the share of immigrants born in new source countries was as high as $40 \%$.

Europeans from new regions were culturally farther from natives and significantly less skilled than those from old sending regions (Hatton and Williamson, 1998, 2006). The shift in the composition of immigrants and concerns over their assimilation induced Congress to establish a commission that, between 1907 and 1911, studied the economic and social conditions of immigrants (Higham, 1955). In 1911, the Immigration Commission recommended the introduction of immigration restrictions, and in 1917, after decades of heated political debate, Congress passed a literacy test requiring that all immigrants entering the United States had to be able to read and write (Goldin, 1994).

Even before the adoption of the literacy test, in 1914, the Age of Mass Migration came to an abrupt end due to the onset of World War I, which drastically reduced European immigration between 1915 and 1919 (see Figure A.2). In 1920, despite the literacy test, migration flows increased again to their 1910 levels, fuelling nativist movements and generating even stronger political pressure to adopt more effective measures to curb immigration. In response to the growing demand for immigration restrictions, in 1921 and 
1924 Congress finally passed the Immigration Acts to limit the number of immigrants that could enter the United States in a given year by introducing country-specific quotas based on 1890 immigrants' population. ${ }^{4}$

Both World War I and the Immigration Acts affected different sending countries in different ways. In particular, the reduction in immigration was more pronounced for European regions that were more directly involved in the War and which did not belong to the Allies (Figure 3, Panel A). Moreover, during the 1920s, quotas were set so as to limit the inflow of immigrants from new sending regions, while favoring that from old sources such as the UK, Germany, and Scandinavia (Figure 3, Panel B). Since immigrants tend to cluster along ethnic lines (Card, 2001; Lafortune and Tessada, 2014), the post-1915 events generated substantial variation in the number as well as in the mix of immigrants received by US cities over time (Figure A.3): this is the variation that we exploit in our empirical analysis.

\subsection{Immigration, Natives' Marriage, and Fertility}

During the Age of Mass Migration, many prominent scholars expressed concerns over the effects of immigration on natives' fertility and marriage. As discussed in Leonard (2005), Edward Ross was among the first to propose the theory of "race suicide". According to this theory, not all immigrants were the same, and members of new, inferior races (i.e. immigrants from new sending regions) would eventually outbreed the "superior national stock" (i.e. natives and immigrants from old source countries) because industrial capitalism was conducive to the survival of the unfit (Leonard, 2005). More specifically, Francis A. Walker argued that "the native element failed to maintain its previous rate of increase because the foreigners came in such swarms", and natives were unwilling not only to engage in competition with "these new elements of the population", but also, they did not want "to brings sons and daughters into the world to enter that competition" (Walker, 1899, p. 424).

In contrast with these predictions, the inflow of immigrants might have increased marriage rates and fertility of native women by altering sex ratios (i.e. the relative number of men and women). At the time, more than $60 \%$ of immigrants entering the United States were young men between 20 and 35 (Figure A.1). Since in the early twentieth century the median age at first marriage was around 21 for women and 25 for men (Figure 4), even though marriage markets were highly segmented along ethnic lives and native women

\footnotetext{
${ }^{4}$ With the 1924 National Origins Act, the total number of immigrants that could be admitted in a given year was capped at 150,000. In 1921, quotas were specified reflecting the 1910 composition of immigrants. However, they were rapidly changed to 1890 to limit immigration from new sending countries even further (Goldin, 1994).
} 
loss their U.S. citizenship after marrying a foreign born ${ }^{5}$, immigration might have made it easier for native women to find a mate and to have kids (Angrist, 2002). ${ }^{6}$

Yet another possibility is that immigration affected natives' marriage, fertility, and trends in family formation by altering employment and occupational standing of native men. Historical accounts tend to view immigrants as one of the key determinants of American industrialization and economic development during the Age of Mass Migration. When describing the economic impact of European immigrants, historian Maldwyn Jones wrote that "The realization of America's vast economic potential has...been due in significant measure to the efforts of immigrants. They supplied much of the labor and technical skill needed to tap the underdeveloped resources of a virgin continent" (Jones, 1992, pp. 309-310). Similarly, John F. Kennedy argued that "every aspect of the American economy has profited from the contribution of immigrants" (Kennedy, 1964, p. 88).

During the Age of Mass Migration, the US economy had large potentials for growth. In this context, immigrants provided a cheap and unskilled supply of labor which could not only be absorbed, but that may have even allowed industries to expand (Foerster, 1924), in turn creating new job opportunities for native workers (Tabellini, 2017). It is thus possible that, by increasing the supply of "marriageable men", immigration raised fertility and marriage rates not only of native women, but also of native men. Moreover, if native men could find a stable job earlier in their working life, they might have been able to leave their parental house and set up their own household earlier. Somewhat ironically, then, immigration might have had exactly the opposite effect relative to what was argued by advocates of the theory of "race suicide".

\section{Data}

Our analysis is based on a balanced panel of the 180 US cities with at least 30,000 residents in each of the three census years from 1910 to 1930, and where at least some Europeans were living in 1900 (see Figure A.4 and Table A.2 for the complete list of cities). ${ }^{7}$ The dataset used in this paper was assembled using the decennial US Census of Population, made available by IPUMS (Ruggles et al., 2015). ${ }^{8}$ From this source, we

\footnotetext{
${ }^{5}$ The loss of citizenship after the marriage with an "alien" men was established by Section 3 of the Expatriation Act of 1907. The law was aimed at avoiding cases of multiple nationality among women.

${ }^{6}$ In particular, Figure 4 plots the distribution of the age at first marriage for native men and women in 1930 (the first year in which this question was asked in the US Census). See also estimates reported at https://www.thespruce.com/estimated-median-age-marriage-2303878.

${ }^{7} \mathrm{We}$ focus on the 180 largest cities as these places attracted more than $75 \%$ of the immigrants entering the United States after 1900. It might be of independent interest to repeat the analysis focusing on rural areas as well.

${ }^{8}$ For 1900 , we used the $5 \%$ sample, while for 1910, 1920, and 1930, we relied on the full count census datasets.
} 
collected data on city population, on the number of immigrants by country of origin at the city and at the national level, and on most of the outcomes considered in our analysis, including marital status, relationship to the household head, and the number of children. ${ }^{9}$ To investigate the mechanisms, we also collected data on employment, labor force participation, and occupation of native men of age 20 to 65 from the US Census, and on several measures of economic activity and industrialization from the 1904 to 1929 quinquennial Census of Manufactures (Tabellini, 2017). ${ }^{10}$

Table 1 reports the summary statistics for the main variables used in our analysis. City population ranges from more than 6.9 million (New York City in 1930) to as little as 30,200 (Pasadena in 1910). There is also wide variation in the fraction of immigrants across cities and over time, which was higher in the northeastern states of Connecticut, Massachusetts, New Jersey, and New York, and lower in the US South. As already discussed in Section 2, World War I and the Immigration Acts drastically reduced immigration: in 1910, the fraction of immigrants over city population was, on average, 0.18, but this number fell to 0.12 in 1930 . The decline in the fraction of foreign born that entered the United States in the previous decade was even starker: for the average city, this number was 0.08 in 1910, but fell to 0.02 in 1930 .

In Panel B of Table 1, we report the summary statistics of the main outcomes of this paper, i.e. marriage rates, fertility, and the propensity to leave the parental house for young native men and women. By the age of 33 for women and 35 for men, $65 \%$ of the native population was married. As shown in Table 2 for 1910, among native women of native parentage, $73 \%$ were married to a native husband with both native parents, $20 \%$ to a husband with one or both foreign born parents, and only $8 \%$ to a foreign born husband. Interestingly, most of the foreign born husbands arrived to the US more than ten years before. ${ }^{11}$ Instead, the probability of being married with a foreign born husband was as high as $24 \%$ for second generation women. ${ }^{12}$

Between 1910 and 1930, among women aged 18-33, the average children to women ratio was $0.65: 34 \%$ of native women had at least one child, while those who were mothers had on average almost 2 children each. Table 1 also suggests that the decision of leaving parents' home was strongly correlated with financial independence and with the choice of getting married: the proportion of men and women who were household head or spouse was close to marriage rates ( $45 \%$ and $43 \%$ for women and men respectively).

\footnotetext{
${ }^{9}$ See Table A1 for the list of European countries used in our work. To classify individuals based on their country of origin, we followed the classification made by IPUMS (Ruggles et al., 2015).

${ }^{10}$ In 1920 , the US Census did not report employment status, but rather only an indicator for holding any gainful occupation. For this year, we imputed values from the latter to proxy for employment.

${ }^{11} \mathrm{We}$ analyze the impact of immigration in the previous decade on natives' marriage rates. As shown in Table 2, very few native women were getting married to the immigrants just arrived to the US.

${ }^{12}$ In our sample, second generation women accounted for roughly one forth of all native women.
} 
Finally, Panel C presents the summary statistics for the key labor market outcomes considered below. In 1910, the average employment to population ratio for native men aged 20-35 in our sample was $91 \%$, and then fell to $84 \%$ in 1930 , with the onset of the Great Depression. Average labor force participation for native women was $42 \%$, with an increasing trend over time which was slowed down by the economic downturn in $1930 .{ }^{13}$

Immigration data are available for all the 540 city-year observations in our sample. However, for 1920, Sacramento (CA) and New Bedford (MA) had unreasonably low values for marriage, fertility, and the other demographic outcomes considered in our work, probably reflecting mis-reporting in the original documents. For this reason, in our baseline specification, we drop 1920 data for these two cities, but our results remain unchanged when all 540 city-year observations are included. ${ }^{14}$

\section{Empirical Strategy}

In this section, we present the baseline estimating equation (Section 4.1), construct the instrument for immigration (Section 4.2), and report first stage results (Section 4.3). To deal with the potential endogeneity of immigrants' location decision, we instrument the actual number of immigrants by interacting 1900 settlements of different ethnic groups with subsequent migration flows from each sending region, leaving out immigrants that eventually settled in the city's MSA.

\subsection{Baseline Estimating Equation}

To investigate the effects of immigration on natives' marriage, probability of having children, and family structure across US cities, we stack the data for the three Census years between 1910 and 1930, and estimate

$$
y_{c s t}=\gamma_{c}+\delta_{s t}+\beta \operatorname{Imm}_{c s t}+u_{c s t}
$$

where $y_{c s t}$ is the outcome for city $c$ in state $s$ in Census year $t$, and $I m m_{c s t}$ refers to the fraction of immigrants received by city $c$ in the previous decade, over city population. $\gamma_{c}$ and $\delta_{s t}$ are city and state by year fixed effects, implying that $\beta$ is estimated from changes in the fraction of immigrants within the same city over time, compared to other cities in the same state in a given year. Since city population could itself be an outcome of

\footnotetext{
${ }^{13}$ Until 1930, the US Census classified individuals as participating in the labor force if they were holding any gainful occupation.

${ }^{14}$ Also, data from the Census of Manufactures were not available for Superior (WI), Washington DC in 1909 and 1919, and for Flint (MI), Galveston (TX), Huntington (WV), Lexington (KY), McKeesport (PA), Pueblo (CO), Quincy (IL), and Roanoke (VA) in 1929.
} 
immigration, the number of immigrants is scaled by predicted (rather than actual) city population, constructed by multiplying 1900 population by average urban growth in the US, excluding that of the Census division where the city is located. Below, we also report results obtained when scaling immigration by 1900 population. Standard errors are clustered at the MSA level, and MSA boundaries are fixed to 1940 in order to keep geography constant. ${ }^{15}$

\subsection{Instrument for Immigration}

A priori, we may expect immigrants to be attracted to cities with better employment opportunities. Alternatively, immigrants might settle in otherwise declining cities, where house prices are lower. In either case, OLS estimates of equation (1) will likely be biased. To deal with this endogeneity problem, we construct a "leave-out" version of the shift-share instrument (Card, 2001). The instrument predicts the number of immigrants received by US cities over time by interacting 1900 settlements of different ethnic groups with subsequent migration flows from each sending region, excluding individuals that eventually settled in a given city's MSA. Formally, $\operatorname{Imm}_{c s t}$ in (1) is instrumented with

$$
Z_{c s t}=\frac{1}{\hat{P}_{c s t}} \sum_{j} \alpha_{j c} O_{j t}^{-M}
$$

where $\hat{P}_{c s t}$ is predicted city population; $\alpha_{j c}$ is the share of individuals of ethnic group $j$ living in city $c$ in 1900; and $O_{j t}^{-M}$ is the number of immigrants from country $j$ that entered the US between $t$ and $t-1$, net of those that eventually settled in city $c$ 's MSA. ${ }^{16}$

The instrument constructed in equation (2) exploits two sources of variation: first, cross-sectional variation in the share of individuals from each ethnic group living in different US cities in $1900\left(\alpha_{j c}\right)$; second, time-series variation induced by changes in the total number of immigrants from any sending region entering the United States in a given decade $\left(O_{j t}^{-M}\right)$. Appendix B presents a simple example to illustrate graphically how the instrument combines them.

\footnotetext{
${ }^{15}$ In our baseline specification, we restrict attention to European immigrants that entered the United States during the previous decade, but results are robust to using immigrants' stock or considering immigrants from all sources.

${ }^{16}$ A similar "leave-out" strategy is used in Burchardi et al. (Forthcoming). Results are also robust to using a specification where the endogenous regressor, $\mathrm{Imm}_{c s t}$, is constructed by scaling the number of immigrants by actual (rather than predicted) city population, and is instrumented with $Z_{c s t}$ in (2), i.e. the predicted number of immigrants over predicted city population.
} 


\subsubsection{Geographic Variation in Immigrants' Settlements}

The cross-sectional variation underlying the instrument in equation (2) is based on the idea that immigrants cluster geographically and when newcomers arrive, they tend to move where their ethnic community is larger because of social networks and family ties, and not because of local pull factors (Card, 2001; Stuart and Taylor, 2016). As documented in Sequeira et al. (2017), the gradual expansion of railroads during the nineteenth century is a strong predictor of the geographic distribution of immigrants in the US: places that gained access to the railroad just before an immigration boom received more immigrants in the following decade. Moreover, upon arrival, early settlers tended to locate in places that were relatively more attractive at that time. Since the timing of outmigration varied widely across European countries, depending on local political and economic conditions (Hatton and Williamson, 1998), different US regions were populated by different ethnic groups before 1900. Early settlers then acted as a catalyst for subsequent migrants from the same ethnic group (Lafortune and Tessada, 2014).

To visually display the degree of geographic concentration of different ethnic groups, Figure 5 plots the share of individuals from different European regions living in selected US cities in 1900. ${ }^{17}$ For example, while Italian communities were present in Boston, Philadelphia, and San Francisco, they were practically non-existent in Minneapolis. On the other hand, while almost $4 \%$ of Swedes living in the US in 1900 were settled in Minneapolis, less than $1 \%$ of them were located in north-eastern cities like Philadelphia or Boston. Finally, in 1900, more than $8 \%$ of Eastern Europeans were living in Cleveland, but their share in the other cities displayed in Figure 5 was well below 1\%. Presenting a similar example for Ohio, Figure A.5 shows that differences in immigrants' settlements existed not only across, but also within states. This is important since our empirical strategy exploits only within state variation in immigration.

\subsubsection{Identifying Assumptions and Instrument Validity}

The key identifying assumption behind the instrument is that cities receiving more immigrants (from each sending area) before 1900 must not be on different trajectories for the evolution of economic and social conditions in subsequent decades. Said differently, outmigration from European regions must be independent of cross-city pull factors systematically related to 1900 settlers' country of origin. For example, between 1910 and 1920, immigration to the US was higher from Poland than from Norway. The exclusion restriction would be violated if this happened because cities that in 1900 had attracted

\footnotetext{
${ }^{17}$ See also Abramitzky and Boustan (2017) for a discussion of the geographic concentration of Europeans in the United States during the Age of Mass Migration.
} 
more Poles were growing more than cities where more Norwegians had moved to in 1900.

Another threat to the validity of the identifying assumption is that the characteristics of cities that attracted early immigrants might have time-varying, confounding effects on migration patterns as well as on changes in the outcomes of interest. It is possible, for instance, that larger urban centers attracted more immigrants in the nineteenth century, and that these cities kept growing more also in subsequent decades (see also GoldsmithPinkham et al., 2018). In turn, more sustained economic growth may have increased marriage and fertility of natives, invalidating the instrument constructed in equation (2). To deal with these and similar issues, we perform several robustness checks, which we describe below when presenting our main results.

Finally, the recent work by Jaeger et al. (2018) shows that classic shift-share instruments may suffer from serial correlation in immigration flows from the same sending countries to the same set of receiving areas. An appealing feature of our setting is that both WWI and the Immigration Acts created a clear break not only in the number but also, and crucially, in the countries of origin of immigrants over time. As a result, the potential threat highlighted by Jaeger et al. (2018) is substantially less severe in this historical context than in the contemporaneous period.

\subsection{First Stage Results}

First stage results for the relationship between actual and predicted immigration are reported in Table 3, after partialling out city and state by year fixed effects. In column 1, the dependent variable is the fraction of immigrants over actual city population, and the regressor of interest is the baseline instrument constructed in equation (2). Columns 2 and 3 replicate column 1 by scaling both the actual and the predicted number of immigrants by, respectively, 1900 and predicted population. In all cases, the F-stat is very high, and there is a strong and significant relationship between the endogenous regressor and the instrument.

Figure 6 plots the residual scatterplot of the regression reported in column 3. As it appears, the city of Passaic (NJ) experienced a large drop in immigration between 1910 and 1930, and one may be concerned that, for this reason, it influences the strength of the first stage. However, omitting this city barely affects the slope of the regression line (see red dashed line in Figure 6). From column 3 onwards, Table 3 presents estimates for specifications where both the actual and the predicted number of immigrants are scaled by predicted city population, and explores the stability of the baseline specification to the inclusion of interactions between year dummies and 1900 city characteristics.

First, we augment the specification reported in column 3 by interacting the 1900 (log 
of) city and immigrants' population (column 4). ${ }^{18}$ Next, in columns 5 and 6, we include interactions between year dummies and, respectively, the 1904 ( $\log$ of) value added by manufacture and men in 1900. Even though the F-stat falls relative to column 1, it remains well above conventional levels. Also, and importantly, neither the economic nor the statistical significance of coefficients is affected.

Overall, Table 3 suggests that there is a strong relationship between actual and predicted immigration, which is robust to the use of different specifications and alternative ways of constructing the instrument.

\section{Main Results}

In this Section, we present three sets of results. First, immigration had a positive and large effect on marriage rates of both native women and native men (Section 5.1). Second, the inflow of immigrants raised the probability of having children for natives by increasing the share of young women with at least one child (Section 5.2). Third, immigration induced native young men and women to leave earlier their parental house (Section 5.3).

\subsection{Immigration and Marriage Rates of Natives}

In Table 4, we study the impact of immigration on natives' marriage focusing on the age groups with the highest marriage rates, i.e. women aged 18-33 and men aged 20-35. ${ }^{19}$ In Panel A (resp. Panel B), the dependent variable is the fraction of native women (resp. men) who were married. OLS results of equation (1) are presented in column 1, while column 2 reports 2 SLS estimates for the baseline specification, where we instrument the fraction of immigrants over predicted population using the "leave-out" shift-share instrument described in Section 4.2. Throughout the paper, we always report the mean of the dependent variable at baseline and the F-stat associated with first stage results shown in Table 3.

Starting from Panel A, both OLS and 2SLS estimates suggest that immigration increased marriage rates for native women aged 18-33. These effects are not only statistically significant but also economically relevant: the coefficient in column 2 implies that one standard deviation increase in the fraction of immigrants raised marriage rates of native women aged $18-33$ by $2.2 \%$ relative to the 1910 mean (see Figure 7). Panel B

\footnotetext{
${ }^{18}$ This check is important since the instrument mechanically predicts higher immigration to cities that had a larger 1900 fraction of immigrants, and, at the same time, larger ethnic enclaves might have direct and time-varying effects on economic and social conditions.

${ }^{19}$ As discussed in Section 2.2, the median age at first marriage was around 21 for women and 25 for men (Figure 4).
} 
documents a similar pattern (both qualitative and quantitative) for native men aged 20-35: a five percentage point increase in immigration (equivalent to a one standard deviation) raised men's marriage rates by $2.1 \%$ relative to their baseline mean. ${ }^{20}$ Our findings are quantitatively close to those obtained in Autor et al. (2018), who document that, over the last thirty years, a one percentage point increase in import competition from China lowered female marriage rates by $1.8 \%$

Subsequent columns of Table 4 explore the robustness of our baseline results. First, in column 3, we test for pre-trends by regressing the 1900 to 1910 change in marriage rates against the 1910 to 1920 instrumented change in immigration. Reassuringly, in both Panel A and Panel B, the coefficient on immigration is statistically indistinguishable from zero and different from that reported in column 2. Next, in columns 4 and 5, we augment our baseline specification by interacting year dummies with the (log of) 1900 city and immigrants' population and the 1900 marriage rates, respectively. This exercise is performed to check that results in column 2 are not due to city-specific characteristics that may have simultaneously attracted more immigrants before 1900 and affected the evolution of natives' marriage rates in subsequent decades. In all cases, the point estimate remains statistically significant and quantitatively close to that estimated in the baseline specification. Finally, in column 6 we provide evidence that results are robust to scaling both the actual and the predicted number of immigrants by 1900, rather than predicted, population.

Up to now, we reported results for the "marriage-relevant" age groups by gender. In Figure 7 , we separately document the effect of immigration on marriage rates of native men and women for different age groups. All of the effect estimated in Table 4 comes from the youngest cohorts: one standard deviation increase in the fraction of immigrants raised marriage rates of native women aged $18-25$ and men aged $20-27$ by $3.4 \%$ and $4.0 \%$, respectively, relative to their baseline means. Instead, the effect of immigration is not statistically significant for older cohorts. The point estimates and standard errors related to this figure are reported in Appendix Table A.4, where we also show the probability of being never married for the oldest cohorts. While immigration had no effect on the probability of being never married for men, it lowered the likelihood that women aged 34-65 remained unmarried.

\footnotetext{
${ }^{20}$ OLS estimates are sensitive to the inclusion of three cities (Duluth, Superior, and Tacoma) for which in 1910 marriage rates were very low. The mean value of marriage rates of men aged 20-35 in 1910 is 24 percentage points lower compared to the mean value of the same cities in 1920 and 23 percentage points lower compared to other US cities in our sample in 1910. The latter effect corresponds to 4.6 lower standard deviations in the marriage rates of men in these cities compared to the rest of our sample. In the Appendix Table A.3, we present estimates of OLS and 2SLS results with and without these three cities. Once we restrict the sample, OLS and 2SLS are closer in magnitude.
} 


\subsection{Immigration and Natives' Probability of Having Children}

In Table 5, we study how exposure to immigration affected the probability of having children for native women in our sample of 180 cities. The first two columns focus on the children to women ratio, while in subsequent columns we separately analyze the effect of immigration on the extensive and the intensive margin. We define the former as the share of women with at least one child, and the latter as the children to mothers ratio. In odd (resp. even) columns, the dependent variable is the total number of children in the household (resp. children below the age of 5). Since full-count data allow to match mothers with children only if they are living in the same household, we restrict the sample to women aged 18-33, whose children are likely to live with their parents. ${ }^{21}$

Both OLS and 2SLS results, reported in Panels A and B respectively, document a positive and significant relationship between immigration and the probability of having children of native women. The point estimate in column 1 of Panel B implies that a one standard deviation increase in immigration raised the children to women ratio by $3.3 \%$ relative to its 1910 mean. When decomposing this effect along the extensive and the intensive margin, we note that immigration increased the number of women with children by $2.4 \%$, and raised the average number of children per woman by $1 \%$. Said differently, for every ten new babies born from native women, seven were due to the extensive margin, while three to the intensive margin. The magnitude of the effect is similar when we restrict our attention to children below the age of $5 .^{22}$

Between the late nineteenth century and the 1930s, the US went through a demographic transition, with a reversal of the positive relationship between income and economic growth (Galor and Weil, 2000). The fertility rate of the total white population declined substantially, with the birth rate moving from almost 50 per thousand population in 1850 to 20 per thousand in 1930 (Zelnik, 1959). However, in our analysis, the inclusion of state by year fixed effects takes care of these national trends, since the effect of immigration is estimated from changes in the fraction of immigrants within the same city over time, as compared to other cities in the same state in a given year. Moreover, as noted by Easterlin (1961), the decline in fertility was driven by rural areas; instead, fertility of the urban native (white) population remained stable in this time period. ${ }^{23}$

In Appendix Table A.5, we separately report the effect of immigration on fertility of

\footnotetext{
${ }^{21}$ For data availability issues, it is not possible to match women across Census years to obtain information on completed fertility. Since women changed their surname upon marriage, it is hard to match their information across Census years, especially for those aged 18-33.

${ }^{22}$ As before, our estimates are quantitatively in line with those from Autor et al. (2018), who, for the more recent period, find that a 1 percentage point increase in import competition from China reduced fertility by $2.8 \%$.

${ }^{23}$ Guinnane et al. (2006) find that fertility of immigrants in the late nineteenth and early twentieth century was higher than that of natives, but converged to US standards for second generation immigrants.
} 
native women by age groups. As for marriage, the effect is driven mainly by native women aged 18-25, especially on the extensive margin: one standard deviation increase in immigration raised the number of women in the younger age cohort with at least one child by $3.1 \%$.

\subsection{Household Formation}

In Table 6, we provide evidence that immigration induced natives to leave their parental house earlier, and set up their own independent family unit. In the first two columns, we focus on women aged 18-33, while in subsequent columns we report the effects of immigration on men aged $20-35 .^{24}$

Specifically, the coefficients in Table 6 imply that one standard deviation increase in immigration raised the probability of living in an independent family unit by $2.4 \%$ for women and $2.2 \%$ for men, relative to the mean in 1910 . This effect is quantitatively close to that estimate for marriage rates, suggesting that the decisions of getting married and of leaving the parental house were both part of a unique lifetime plan. ${ }^{25}$

In Figure A.6, we provide evidence that the effect of immigration on the probability of leaving the parental house was driven by women aged 18-25 and men aged 20-27: for these age groups, a five percentage point increase in immigration raised the probability of setting up their own household by more than 3\%. Incidentally, these cohorts also experienced the largest increase in marriage and fertility because of immigration.

Stitching together the three sets of results presented in this section, our estimates paint a coherent picture of how immigration affected family formation, marriage rates, and fertility of native men and women in the urban early twentieth century US. The inflow of immigrants induced natives to get married more (and, possibly, earlier) ${ }^{26}$; this decision was accompanied by the choice of leaving the parental house and set up an independent family unit. In a period in which oral contraception was not yet available (Bailey, 2006), higher fertility was probably mechanically related to marriage and family formation deci-

\footnotetext{
${ }^{24}$ Both OLS and 2SLS results, reported in Panels A and B respectively, are statistically significant and close in magnitude for women. As for marriage rates, for men, OLS estimates are instead sensible to the inclusion of three cities (Duluth, Superior, and Tacoma). In these cities, only $20 \%$ of men were household head in 1910, as compared to $42 \%$ in 1920 or $39 \%$ in the other cities of our sample in 1910. 2SLS estimates are instead unaffected by the inclusion of these three cities.

${ }^{25}$ Interestingly, focusing on the contemporaneous period, Autor et al. (2018) find that one percentage point increase in import competition from China, not only decreased marriage rates and fertility, but also lowered the probability of living with the spouse by $1.6 \%$.

${ }^{26}$ Using information from the 1940 US census for the same cohorts of individuals of our main specification, we check whether the increase in marriage rates is merely due to marriage at younger age. Although there are some potential concerns related to migration and data quality, we find that individuals in cities exposed to more immigration have overall higher marriage rates during the entire life and slightly lower age at first marriage. The table is available upon request to the authors.
} 
sions.

\section{Mechanisms}

In this section, we explore the mechanisms behind the results presented above, including changes in employment opportunities for native men, changes in sex ratios, natives' cultural responses, and displacement effects of immigrants on female employment. In Section 6.1, we start by documenting that immigration raised employment and occupational standing of native men, and then argue that such higher supply of "marriageable men" was an important driver of the positive effect of immigration on natives' marriage and fertility shown in Section 5. Next, we provide evidence that changes in sex ratios (Section 6.2), natives' cultural responses (Section 6.3), and direct effects of immigration on native female labor force participation (Section 6.4) cannot account for a quantitatively relevant fraction of our main findings.

\subsection{Natives' Employment and the Supply of Marriageable Men}

In two important contributions, Wilson (1987) and Wilson (1996) argues that the decline in marriage and the rise in the share of single-mother households in the US during the last forty years have been, at least in part, due to deteriorating employment opportunities in manufacturing. Along these lines, exploiting exogenous variation in exposure to import competition from China across US local labor markets, Autor et al. (2018) find that job losses in manufacturing caused a steep decline in marriage rates and a significant increase in the proportion of single-mother households. In this section, we investigate the possibility that a similar mechanism, with the opposite sign, was at play in our context. Specifically, we advance and empirically test the hypothesis that immigration had a positive effect on natives' marriage, fertility, and patterns of family formation by increasing employment and occupational standing of native men, in turn raising the supply of "marriageable men".

In Table 7, we study the effects of immigration on natives' employment to population ratio, focusing on men in the "marriageable relevant" age range, i.e. 20-35 (see Section 5.1). As for Table 4, columns 1 and 2 estimate the baseline specification (see equation (1)) with OLS and 2SLS respectively. In both cases, there is a strong and positive relationship between immigration and natives' employment. The coefficient in column 2, which is quantitatively very close to OLS results reported in column 1, implies that a five percentage points increase in immigration (equivalent to one standard deviation) raised natives' employment to population ratio by $0.9 \%$ relative to its 1910 mean. Said differ- 
ently, for every ten new immigrants, one and a half more jobs were created for native men aged 20 to 35 .

As documented in Figure A.7, the effect of immigration is slightly larger for men in the age range 20-27, but remains positive and statistically significant also for those aged 2835. The point estimate is positive and quantitatively very similar, albeit not statistically significant, also for older natives, i.e. those in the age range 36-65. ${ }^{27}$

As we did in Table 4, we next test the robustness of our baseline specification in subsequent columns of Table 7. First, as for marriage rates, there is no evidence of pre-trends (column 3). Second, results are robust to interacting year dummies with the $1900 \log$ of city and immigrants population (column 4) and log of value added by manufacture (column 5). Third, our estimates are unchanged when scaling both the actual and the predicted number of immigrants by 1900 , rather than predicted, city population (column $6)$.

The positive effects of immigration on natives' employment estimated in Table 7 are in contrast with some of the results from the contemporary immigration literature such as Borjas (2003), Borjas and Katz (2007), and Dustmann et al. (2017) who find a negative effect of immigration on natives' labor market outcomes. Our findings are also somewhat different from those of some contemporaneous cross-city design studies that estimate a zero effect of immigration on natives' wages (Card, 2001, 2005). However, they are consistent with a recent body of the literature which documents a positive impact of immigrants on natives' occupational mobility (Foged and Peri, 2016), and more specifically for this historical period with Tabellini (2017).

In line with the latter works, in Figure 8, we show that immigration induced natives to leave occupations that were more exposed to immigrants' competition and to take up jobs where immigrants were prevented from entering, because of skill and language mismatch or because of discrimination. Specifically, Figure 8 plots the implied effect (expressed in percent change) of a one standard deviation increase in immigration on the fraction of native men aged 20-35 employed in specific occupations (see also Table A.6 in the appendix). The first three (orange) bars starting from the left refer to occupations that were highly exposed to immigrants' competition: ${ }^{28}$ as it appears, immigration had a negative effect on the share of young natives working in these occupations. This effect is statistically significant and economically large especially for manufacturing laborers - one of the jobs with the highest exposure to immigrants' competition and with the lowest skill requirements. Moving rightward along the graph, the three (blue) bars on the right show that

\footnotetext{
${ }^{27}$ Similar results are obtained in Tabellini (2017), who studies the effects of immigration on natives' employment in the age range 15-65.

${ }^{28}$ We proxy for the degree of immigrants' competition using the ratio of the probability that natives and immigrants held a given occupation in 1910 (see also Table A.6).
} 
immigration increased the fraction of natives employed in more skilled and less exposed occupations such as manufacturing foremen, electricians, and engineers. The pattern displayed in Figure 8 can be effectively summarized using the words of the economist and statistician Isaac Hourwich who, in 1912, noted that "the effect of immigration upon the occupational distribution of industrial wage earners has been the elevation of the Englishspeaking workmen to the status of an aristocracy of labor, while the immigrants have been employed to perform the rough work of all industries" (Meyer, 1981). The importance of this channel is supported by the evidence on the heterogeneous effects for white and black natives. Differently from Ager and Hansen (2017), we find that immigration had a positive impact on employment only for white natives and no impact on black natives. This effect is mirrored by an increase in marriage rates among white native women and no impact on black native women (see Figure A.8).

For natives' employment to increase, immigration must have also stimulated economic activity, inducing firms to create new jobs. Otherwise, absent changes in labor demand, it would be hard to reconcile the labor supply shock induced by immigration with the positive employment effects estimated above. Consistent with this idea, in Figure A.9, we show that immigration had a positive and large effect on value added (log of value added per establishment), the value of products per establishment, total factor productivity, and capital utilization. ${ }^{29}$ Specifically, the coefficients imply that a one standard deviation increase in immigration increased industrial production by roughly $10 \%$ relative to its 1910 level. Such sizeable effects are not only consistent with the historical literature reviewed in Section 2 and with recent findings in Sequeira et al. (2017) and Ager and Hansen (2017), but also, and importantly, can explain the positive employment effects estimated in Table 7. On the one hand, industrial expansion allowed the economy to absorb the large supply shock by creating new jobs for both high and low skilled workers. On the other, it provided natives with opportunities for skill upgrading.

Overall, this section documents that immigration boosted natives' employment and induced men to take up better jobs. We argue that, in turn, the larger pool of "marriageable men" was responsible for the positive effects of immigration on natives' marriage rates, fertility, and propensity to leave the parental household earlier. In Table A.7, we provide an additional piece of evidence consistent with this interpretation by showing that immigration lowered the share of children below the age of 10 born from native parents living in a household where the father was unskilled (column 1). ${ }^{30}$ Similarly, even if the coef-

\footnotetext{
${ }^{29}$ We proxy for capital utilitazion using the log of horsepower, and estimate the effects of immigration on TFP productivity, assuming a Cobb-Douglas production function with two factors of production, capital and (homogeneous) labor.

${ }^{30}$ OLS and 2SLS results are reported respectively in Panel A and Panel B. Very similar results are obtained when focusing on the share of families rather than on the share of children (see columns 3 and 4).
} 
ficient is not statistically significant at conventional levels, there is a positive relationship between immigration and the share of children of native parentage whose father was employed. These results suggest that, because of immigration, children of native parentage were likely to grow up in a better environment at home.

Consistent with the latter observation, as it appears from Table A.8, immigration increased the fraction of sons of native parentage aged 6-14 who were enrolled in school (column 1). ${ }^{31}$ Somewhat interestingly, though, we do not find a similar effect for daughters (column 4), even if the 1910 average enrollment was very similar for boys and girls. One possible explanation for this pattern is that families were credit constrained and, as more resources became available, parents chose to first invest them in sons rather than in daughters. Especially in an urban context, higher employment opportunities brought about by immigration might have increased the opportunity cost of schooling, in turn inducing some boys to opt out of high school. Indeed, column 3 of Table A.8 shows that immigration had a negative and significant effect on enrollment of sons of native parentage aged 15-18.

\subsection{Changes in Sex Ratios}

The literature has documented that sex ratios, i.e. the relative number of men and women, can be an important determinant of marriage and family formation decisions (Angrist, 2002; Abramitzky et al., 2011; Lafortune, 2013). Since more than $60 \%$ of immigrants entering the United States at the beginning of the twentieth century were young men (Figure A.1), immigration likely altered sex ratios, possibly increasing the availability of potential mates for native women. However, in this section, we argue that this channel cannot explain a relevant fraction of our main results.

First, while changes in the relative number of men and women might have contributed to the increase in marriage rates and fertility of native women documented above, they cannot explain why immigration also raised native males' marriage rates. ${ }^{32}$ Second, as we show in column 3 of Table 8 and Table A.9, only $4 \%$ of native women had a foreign born husband and $3 \%$ of native men had a foreign born wife as of $1910 .{ }^{33}$ Also, the increase in marriage rates for men and women was quantitatively similar (see Table 4), suggesting that natives, in most cases, were marrying with each other. Said differently,

\footnotetext{
${ }^{31}$ As before, Panel A and Panel B report OLS and 2SLS results respectively.

${ }^{32}$ Indirectly, higher competition in the marriage market may have induced men to increase their investment in education and on-the-job training and their earnings, as suggested by Becker (1981) in his notion of male "efficiency" (see also Angrist, 2002). However, even in this case, changes in sex ratios should have had a stronger impact on women as compared to men.

${ }^{33}$ In Table 8 and Table A.9, we explore the characteristics of partners of native women aged 18-33 and men 20-35 respectively.
} 
marriage markets at the time were highly segmented along ethnic lines (Angrist, 2002).

Focusing on results reported in Table 8, in Panel A, we find that one standard deviation increase in immigration raised the probability of getting married with a husband of native parentage by around $6 \%$ for all native women, irrespective of their parentage (columns 2 and 5). Instead, while the effect of immigration on the probability of having a foreign born spouse for native women was indistinguishable from zero (column 3), it was positive and significant for second generation women (column 6). ${ }^{34}$ Yet, focusing on the relevant age group (i.e. 18-33), since second generation women who had a foreign born husband represented less than $2.5 \%$ of all native women, the implied effect of immigration on the overall marriage rates of native women was negligible. ${ }^{35}$ Finally, Panel B documents that these effects were mirrored by a corresponding increase in fertility precisely for couples with higher marriage rates, in turn supporting the idea that immigration raised natives' fertility by fostering marriage in an era when oral contraception was not yet available (Bailey, 2006).

Having established that most of the effects of immigration were not driven by native women marrying foreign born husbands, in the last part of this section, we study how the inflow of immigrants affected marriage prospects of second generation men and women, via changes in sex ratios. Sex ratios can have important implications for the marriage market of second generation immigrants, both directly and indirectly through the allocation of bargaining power within the couple. For example, in the same historical context of our paper, Angrist (2002) finds that a higher relative number of men in their own ethnic group improved marriage prospects of second generation females. Figure 9 documents a pattern in line with this idea: because of immigration, marriage rates of second generation women aged 18-25 increased twice as much as those of women of native parentage. Similarly, while immigration had a positive and large effect on marriage rates for men of native parentage, it did not have any significant impact for second generation men. This finding is consistent with the idea that immigrants increased competition in the marriage market for second generation men. In Table A.10, we separately report the effect of immigration on marriage rates of native men and women for different age groups and parentage, and document that all of the effect comes from the youngest cohorts represented in Figure 9 (that is, women aged 18-25 and men aged 20-27).

To sum up, even though sex ratios were affected by immigration, they can hardly explain the increase in marriage rates of natives with native parentage, a group for which

\footnotetext{
${ }^{34}$ Interestingly, Table A.9 shows a similar impact of immigration on marriage rates for all native and second generation men. While the effect of immigration on the probability of having a foreign born spouse is indistinguishable from zero for native men (column 3), the impact is positive and significant for male second generation immigrant (column 6).

${ }^{35}$ In the age group $18-33$, second generation women were $25 \%$ of native females, and their probability of marrying with a foreign born was $10 \%$ at baseline (see the last column of Table 8).
} 
the relative number of men and women in the reference population was not significantly affected. Since natives of native parentage were by far the largest group among US born individuals, their decisions disproportionately affected natives' overall marriage and fertility.

\subsection{Preservation of "Natives"}

Opposition to immigration was widespread during the Age of Mass Migration, with a heated aversion towards individuals coming from non Anglo-Saxon and non Englishspeaking countries (Abramitzky and Boustan, 2017; Leonard, 2016). Since immigrants from Southern and Eastern Europe were linguistically and culturally far from natives (Hatton and Williamson, 2006), it is possible that natives reacted to immigration by marrying more and having more kids, in order to preserve their own race and culture (see Section 2.2).

The role of culture in affecting marriage and fertility decisions has been stressed, among others, by Bisin and Verdier (2000) and Fernández and Fogli (2006), who study the transmission of cultural norms among second generation immigrants in the US. ${ }^{36}$ More broadly, social interactions can influence the diffusion of cultural norms and have historically contributed to the convergence of fertility rates, both within and across countries (Spolaore and Wacziarg, 2016). For instance, Daudin et al. (2016) find that the demographic transition at the end of the nineteenth century in France was affected by the diffusion of low-fertility norms through internal migration.

To test if native men and women changed their family formation decisions to preserve their own culture, we analyze whether the effect on marriage rates and fertility was stronger when natives were exposed to linguistically farther individuals (which we take as a proxy for cultural distance). Specifically, we construct an index of immigrants' linguistic distance from English, $L D_{c t}=\sum_{j}\left(s h_{c t}^{j} L^{j}\right)$, where $s h_{c t}^{j}$ is the share of ethnic group $j$ among the foreign born population of city $c$ in year $t$, and $L^{j}$ is the linguistic distance from English of country $j$, computed in Chiswick and Miller (2005). ${ }^{37}$ To ease the interpretation of results, which are reported in Table 9, we standardize our measure of linguistic distance by subtracting its mean and dividing it through its standard deviation. Differently from what we would have expected if this mechanism was driving our results, marriage rates were not differentially affected by immigrants with different linguistic distance from English. These results thus suggest that cultural considerations were unlikely

\footnotetext{
${ }^{36}$ Interestingly, in our context, we find that native men and women married to a foreign born were almost exclusively matching in the marriage market with immigrants from old sending regions who were culturally more similar to US born.

${ }^{37}$ We instrument the actual ethnic shares $s h_{c t}$ using the same logic of the instrument constructed in equation (2).
} 
to explain our key findings.

\subsection{Increased Labor Market Competition for Women}

From the end of the nineteenth century to the 1920s, female workers were mainly young, unmarried, and from low-income households (Goldin, 2006). Most women were employed as piece workers in manufacturing, as private household workers or laundresses, or in clerical jobs. Upon getting married, women typically quitted their jobs because of the stigma attached to wives working outside their home (Cherlin, 2014). Goldin (1990) estimates that more than $80 \%$ of all married women exited the labor force at marriage, before 1940 (see Goldin, 1990, page 7). As shown in Table A.11, in our sample of cities, the 1910 average labor force participation of native women aged 18-25 was 0.49 , but was substantially lower for older women (0.33 and 0.25 for women aged 26-33 and 34-65, respectively). ${ }^{38}$

Studying the link between immigration, female labor force participation, and fertility, Furtado (2016) shows that the availability of lower cost childcare opportunities brought about by immigration induced native women to have more kids and work longer hours. In contrast with these results, at the beginning of the twentieth century, immigration may have increased competition in the labor market for women, in turn inducing them to first leave their job and then, as a consequence, to get married and have more children (Angrist and Evans, 1998). While possible, this interpretation seems to be inconsistent with the historical context studied in our paper: at that time, as already discussed above, women most frequently took care of their own children, and used to quit their job upon marriage. Moreover, even though immigrants provided a cheap and unskilled supply of labor, which in principle might have displaced women, during the Age of Mass Migration, the US economy had large potential for economic expansion (Higgs, 1971). Thus, the displacement of female workers due to immigration seems unlikely, even more so as immigrants were more closely substitutes for men than for women, and we showed above that immigration increased natives' employment (see Section 6.1).

In line with this discussion, in Table A.11, we document that immigration decreased labor force participation only for native women in the age group that experienced a significant increase in marriage rates (i.e., women aged 18-25). The impact is instead indistinguishable from zero for all older age cohorts, including women between 26 and 33 years old, among which one third was in the labor force. ${ }^{39}$ In Figure 10, we report the

\footnotetext{
${ }^{38}$ Goldin (2006) notes that labor force participation of married women may be underestimated before 1940 because they were often reluctant to report that they had a job.

${ }^{39}$ Furthermore, women aged 26-33 were likely to work in the same sectors and occupations as women aged 18-25.
} 
implied coefficients for the effect of a one standard deviation increase in immigration, and show that female labor force participation in the age group 18-25 fell by $1.6 \%$ relative to its 1910 mean. Incidentally, this effect is only slightly smaller (in absolute value) than the increase in marriage induced by immigration for women in the same age group (see Figure 7). Our interpretation of these results is that immigration first induced native women to marry and have children, and then, as a consequence of the latter two decisions, to leave the labor force.

\section{Conclusions}

Today, immigration is at the forefront of the political debate, and there are increasing concerns over its economic and social consequences. If we look at American history, however, this is not the first time that immigration is such a relevant and controversial issue. In fact, at the beginning of the twentieth century, following the inflow of more than 30 million Europeans, the share of foreign born in the US population was even higher than it is today, and opposition towards immigration was widespread.

In this paper, we exploit plausibly exogenous variation in the number of European immigrants to US cities between 1910 and 1930 induced by WWI and the Immigration Acts to study the impact of immigration on marriage rates, the probability of having children, and the propensity to leave the parental house for young native men and women. We find that, by promoting industrial expansion and economic activity, immigration increased the supply of native "marriageable" men who, because of their better employment prospects and occupational standing, became more attractive spouses. This, in turn, fostered natives' marriage rates for both men and women, and induced young adults to leave their parents' house earlier in their life. Higher marriage rates, in a period when oral contraception was not yet available, raised natives' probability of having children, mainly by increasing the number of women with at least one child (extensive margin).

In our context, the inflow of immigrants was largely beneficial to natives' economic and social outcomes. However, this does not imply that immigration will always promote fertility and marriage among young natives. In fact, if immigrants increase labor market competition, they may deteriorate, rather than promote, family stability as well as the environment where children grow up. Moreover, while we showed that in the early twentieth century, immigration to US cities affected marriage rates and fertility of natives mostly through (positive) income shocks, other channels may be at play in other settings. These observations suggest that one needs to be careful when extrapolating our results to other contexts.

Findings in this paper provide motivation for future work in at least two directions. 
First, in this study, we have not explored how changes in the supply of "marriageable men" affected the quality of the match between husbands and wives. If higher marriage rates were associated with worse matching between partners, this might have increased divorce rates and family instability, in turn lowering children's well-being (Stevenson and Wolfers, 2007; Lundberg et al., 2016). Second, it would be interesting to compare our results with those obtained from studies conducted in other contexts, when a different set of channels might be at play.

\section{References}

Abramitzky, R. and L. P. Boustan (2017). Immigration in American Economic History. Journal of Economic Literature.

Abramitzky, R., A. Delavande, and L. Vasconcelos (2011). Marrying up: the role of sex ratio in assortative matching. American Economic Journal: Applied Economics 3(3), $124-157$.

Ager, P. and C. W. Hansen (2017). Closing heaven's door: Evidence from the 1920s US immigration quota acts. Working Paper.

Altonji, J. G. and D. Card (1991). The effects of immigration on the labor market outcomes of less-skilled natives. In Immigration, trade, and the labor market, pp. 201234. University of Chicago Press.

Angrist, J. (2002). How do sex ratios affect marriage and labor markets? Evidence from America's second generation. The Quarterly Journal of Economics 117(3), 997-1038.

Angrist, J. and W. Evans (1998). Children and their parents' labor supply: Evidence from exogenous variation in family size. The American Economic Review.

Autor, D., D. Dorn, G. Hanson, et al. (2018). When work disappears: Manufacturing decline and the falling marriage-market value of young men. The American Economic Review: Insights.

Bailey, M. J. (2006). More power to the pill: the impact of contraceptive freedom on women's life cycle labor supply. The Quarterly Journal of Economics 121(1), 289320.

Becker, G. (1981). A Treatise on the Family. Harvard university press.

Bisin, A. and T. Verdier (2000). Beyond the melting pot: Cultural transmission, marriage, and the evolution of ethnic and religious traits. The Quarterly Journal of Economics 115(3), 955-988.

Borjas, G. J. (2003). The labor demand curve is downward sloping: Reexamining the impact of immigration on the labor market. The Quarterly Journal of Economics 118(4), $1335-1374$. 
Borjas, G. J. and L. F. Katz (2007). The evolution of the Mexican-born workforce in the United States. In Mexican immigration to the United States, pp. 13-56. University of Chicago Press.

Card, D. (2001). Immigrant inflows, native outflows, and the local labor market impacts of higher immigration. Journal of Labor Economics 19(1), 22-64.

Card, D. (2005). Is the new immigration really so bad? The Economic Journal 115(507).

Cherlin, A. J. (2014). Labor's love lost: the rise and fall of the working-class family in America. Russell Sage Foundation.

Chiswick, B. R. and P. W. Miller (2005). Linguistic distance: A quantitative measure of the distance between english and other languages. Journal of Multilingual and Multicultural Development 26(1), 1-11.

Daudin, G., R. Franck, and H. Rapoport (2016). The cultural diffusion of the fertility transition: Evidence from internal migration in 19th century France. CESifo Working Paper.

Dustmann, C., U. Schonberg, and J. Stuhler (2017). Labor supply shocks, native wages, and the adjustment of local employment. The Quarterly Journal of Economics 132(1), 435.

Easterlin, R. (1961). The American baby boom in historical perspective. The American Economic Review 51(5), 869-911.

Fernández, R. and A. Fogli (2006). Fertility: The role of culture and family experience. Journal of the European Economic Association 4(2-3), 552-561.

Foerster, R. F. (1924). The Italian emigration of our times, Volume 20. Harvard University Press.

Foged, M. and G. Peri (2016). Immigrants' effect on native workers: New analysis on longitudinal data. American Economic Journal: Applied Economics 8(2), 1-34.

Furtado, D. (2016). Fertility responses of high-skilled native women to immigrant inflows. Demography 53(1), 27-53.

Furtado, D. and H. Hock (2010). Low skilled immigration and work-fertility tradeoffs among high skilled us natives. The American Economic Review 100(2), 224-228.

Galor, O. and D. N. Weil (2000). Population, technology, and growth: From malthusian stagnation to the demographic transition and beyond. The American Economic Review, $806-828$.

Goldin, C. (1990). The gender gap: An economic history of American women. New York: Cambridge University Press.

Goldin, C. (1994). The political economy of immigration restriction in the United States, 1890 to 1921. In The regulated economy: A historical approach to political economy, pp. 223-258. University of Chicago Press. 
Goldin, C. (2006). The quiet revolution that transformed women's employment, education, and family. The American Economic Review.

Goldsmith-Pinkham, P., I. Sorkin, and H. Swift (2018). Bartik instruments: What, when, why, and how. NBER Working Paper.

Guinnane, T. W., C. M. Moehling, and C. Ó. Gráda (2006). The fertility of the Irish in the United States in 1910. Explorations in Economic History 43(3), 465-485.

Halla, M., A. F. Wagner, and J. Zweimüller (2017). Immigration and voting for the far right. Journal of the European Economic Association.

Hatton, T. J. and J. G. Williamson (1998). The Age of Mass Migration: Causes and economic impact. Oxford University Press on Demand.

Hatton, T. J. and J. G. Williamson (2006). International migration in the long run: Positive selection, negative selection, and policy. In Labor Mobility and the World Economy, pp. 1-31. Springer.

Higgs, R. (1971). The transformation of the American economy, 1865-1914: An essay in interpretation. Wiley New York.

Higham, J. (1955). Strangers in the land: Patterns of American nativism, 1860-1925. Rutgers University Press.

Jaeger, D. A., J. Ruist, and J. Stuhler (2018). Shift-share instruments and the impact of immigration. NBER Working Paper.

Jones, M. A. (1992). American immigration. University of Chicago Press.

Kearney, M. S. and R. Wilson (2017). Male earnings, marriageable men, and nonmarital fertility: Evidence from the fracking boom. NBER Working Paper.

Keeling, D. (1999). The transportation revolution and transatlantic migration, 1850-1914. Research in Economic History 19, 39-74.

Kennedy, P. J. F. (1964). A nation of immigrants. New York: Harper \& Row Publishers.

Lafortune, J. (2013). Making yourself attractive: Pre-marital investments and the returns to education in the marriage market. American Economic Journal: Applied Economics 5(2), 151-78.

Lafortune, J. and J. Tessada (2014). Smooth (er) landing? The role of networks in the location and occupational choice of immigrants. Working paper.

Leonard, T. C. (2005). Retrospectives: Eugenics and economics in the progressive era. The Journal of Economic Perspectives 19(4), 207-224.

Leonard, T. C. (2016). Illiberal reformers: race, eugenics, and American economics in the Progressive Era. Princeton University Press. 
Lundberg, S., R. A. Pollak, and J. Stearns (2016). Family inequality: Diverging patterns in marriage, cohabitation, and childbearing. The Journal of Economic Perspectives 30(2), 79-101.

Mayda, A. M., G. Peri, and W. Steingress (2016). Immigration to the US: A problem for the republicans or the democrats? NBER Working Paper.

Meyer, S. (1981). The five dollar day: Labor management and social control in the Ford Motor Company, 1908-1921. State University of New York Press.

Ottaviano, G. I. and G. Peri (2012). Rethinking the effect of immigration on wages. Journal of the European Economic Association 10(1), 152-197.

Peri, G. and C. Sparber (2009). Task specialization, immigration, and wages. American Economic Journal: Applied Economics 1(3), 135-69.

Porter, E. (2017). Can immigration hurt the economy? An old prejudice returns. The New York Times, February 14, 2017.

Ruggles, S., K. Genadek, R. Goeken, J. Grover, and M. Sobek (2015). Integrated public use microdata series: Version 6.0 [dataset]. Minneapolis: University of Minnesota.

Sequeira, S., N. Nunn, and N. Qian (2017). Migrants and the making of America: The short-and long-run effects of immigration during the Age of Mass Migration. NBER Working Paper.

Spolaore, E. and R. Wacziarg (2016). Fertility and modernity. UCLA CCPR Population Working Papers.

Stevenson, B. and J. Wolfers (2007). Marriage and divorce: Changes and their driving forces. The Journal of Economic Perspectives 21(2), 27-52.

Stuart, B. A. and E. J. Taylor (2016). Social interactions and location decisions: Evidence from US Mass Migration. Working paper.

Tabellini, M. (2017). Gifts of the immigrants, woes of the natives: Lessons from the Age of Mass Migration. Working Paper.

Walker, F. A. (1899). Discussions in economics and statistics, Volume 2. H. Holt.

Wilson, J. W. (1996). When work disappears: The world of the new urban poor. New York: Alfred A Knopf.

Wilson, W. (1987). The truly disadvantaged: The inner city, the underclass, and public policy. Chicago: Univ. Press, Chicago.

Zelnik, M. (1959). Estimates of Annual Births and Birth Rates for the White Population of the United States from 1855 to 1934. Ph. D. thesis, Princeton University. 


\section{Figures and Tables}

Figure 1: Immigrants as Percent of US Population

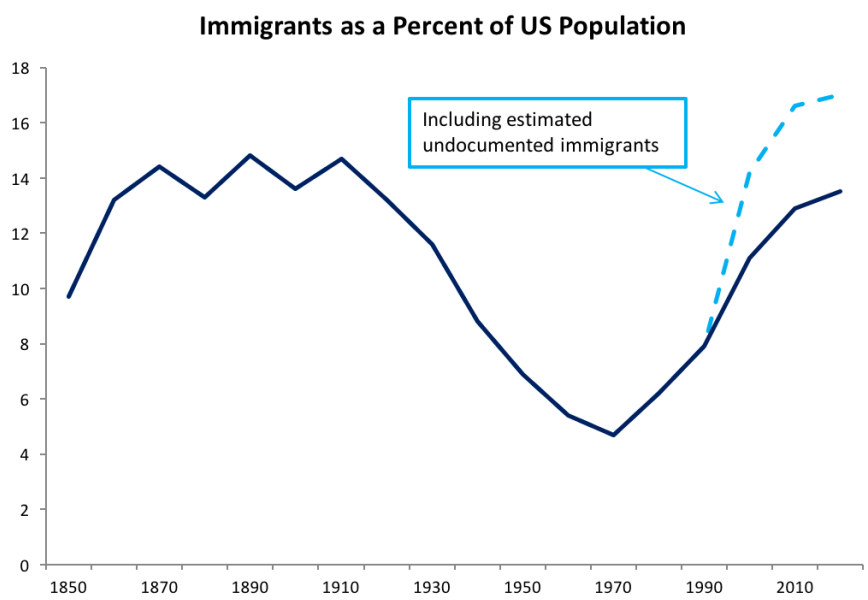

Notes: The solid line shows the number of legal immigrants as a percent of US population. The dashed line includes also the estimated number of illegal immigrants, available from 2000 onwards. Source: the number of legal immigrants comes from the Migration Policy Institute, while the number of illegal immigrants was taken from the Pew Research Center tabulations.

Figure 2: Share of Foreign Born in the US

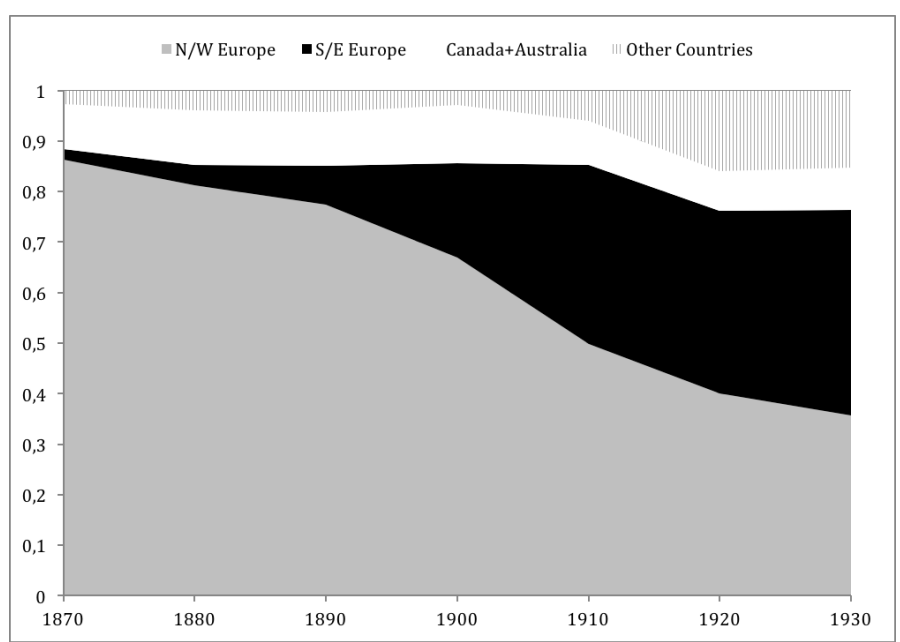

Notes: Share of immigrant stock living in the United States, by sending region and by decade. Source: Authors' calculations from IPUMS sample of US Census (Ruggles et al., 2015). 
Figure 3: The impact of quotas and WWI on the share of immigrants in the USA.

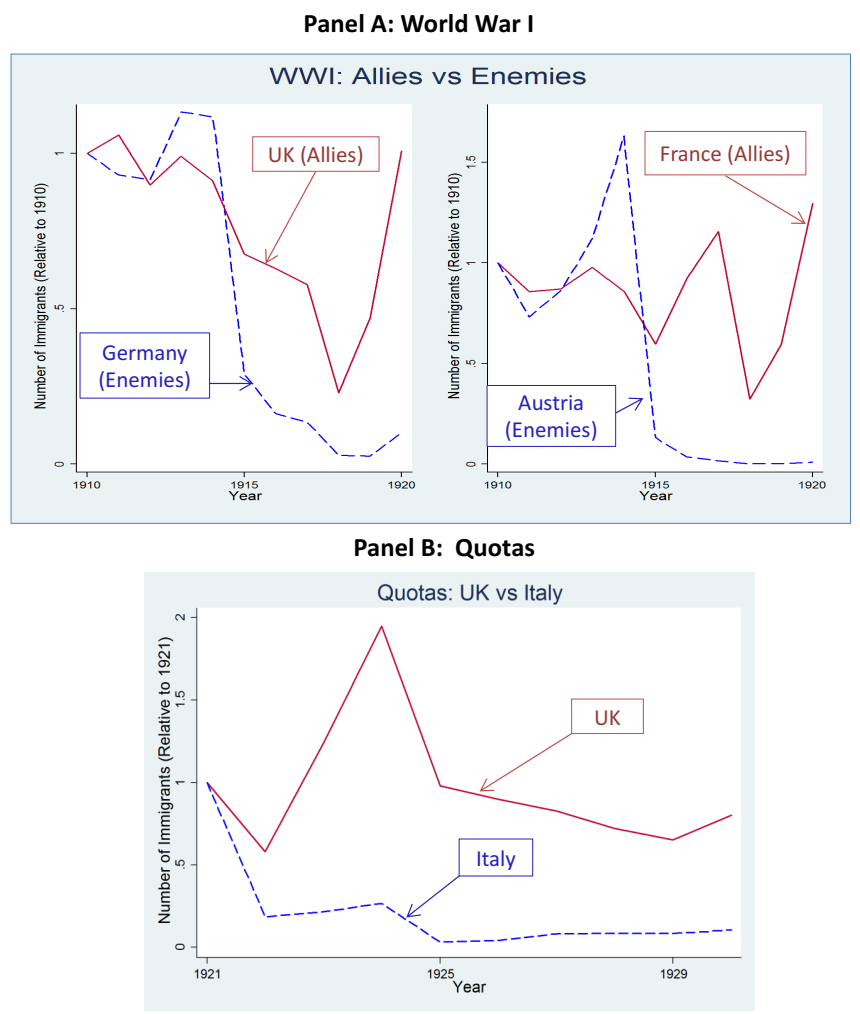

Notes: the figure plots the number immigrants from each European country that entered the United States in each year, scaled by the number of immigrants from that country in 1910 (Panel A) and 1921 (Panel B). Source: adapted from Tabellini (2017). 
Figure 4: Marriage rates by age group and gender

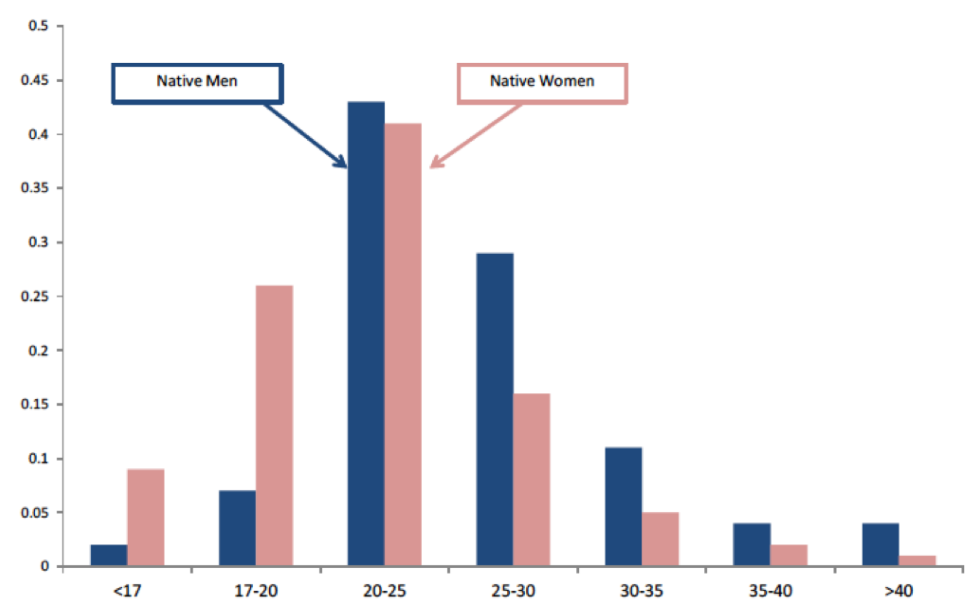

Source: Authors' calculations using IPUMS data.

Figure 5: Share of Immigrants from Selected Regions in US Cities, 1900

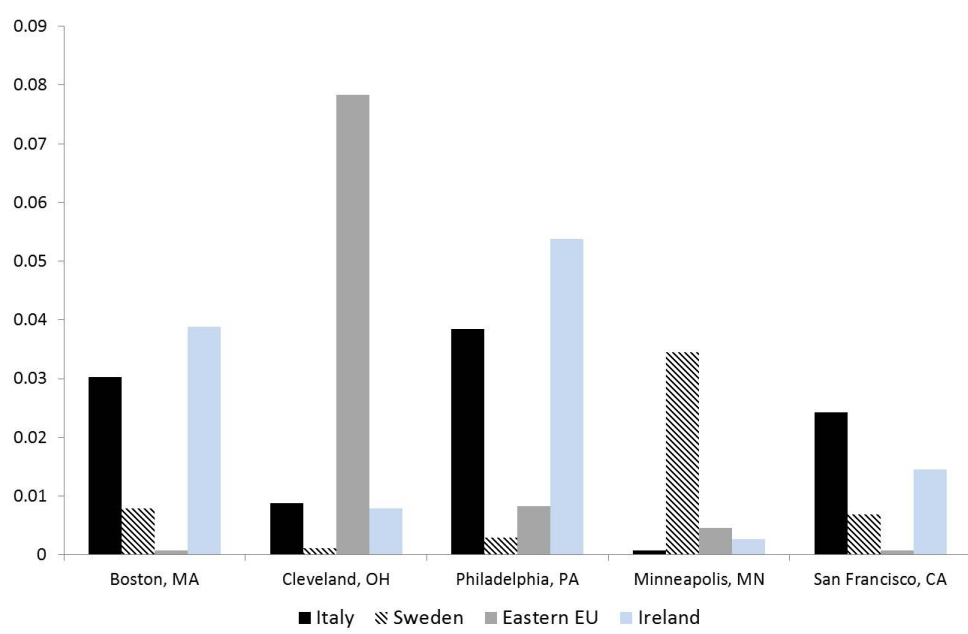

Notes: This graph shows the share of individuals of European ancestry living in US cities in 1900, for selected ethnic groups. Source: Authors' calculations using IPUMS data. 
Figure 6: First Stage

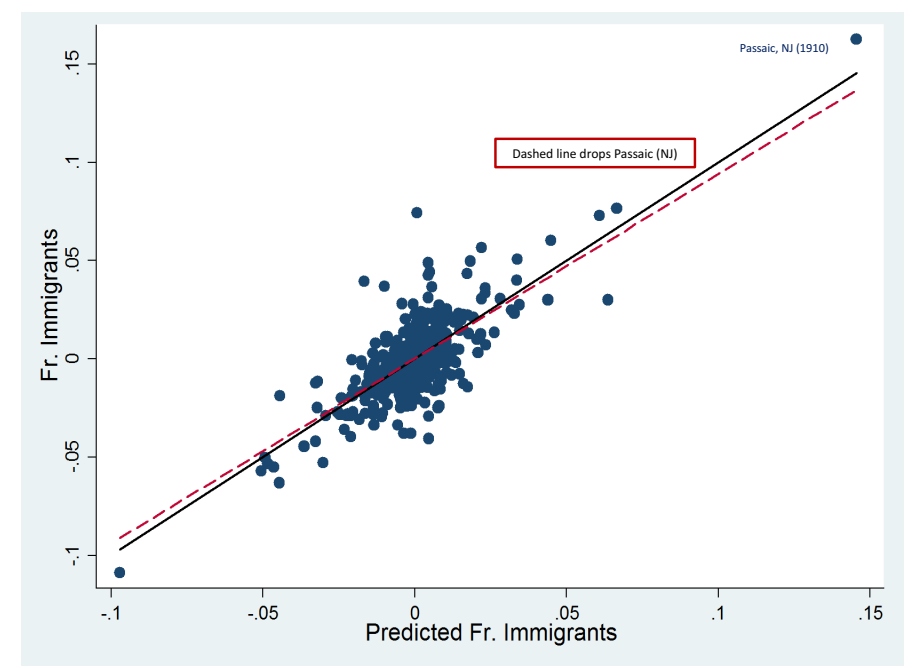

Notes: The y-axis (resp. x-axis) reports the actual (resp. predicted) number of immigrants over predicted city population in each of the three Census years, 1910, 1920, and 1930. Each point in the scatter diagram represents the residual change in a city's actual and predicted fraction of immigrants after partialling out city and year by state fixed effects. The predicted number of immigrants is constructed as discussed in Section 4.2 in the text. Predicted city population is obtained by multiplying 1900 city population with average urban growth, excluding that of the Census division where a city is located. The solid line shows the regression coefficient for the full sample (coefficient $=0.990$, standard error $=0.063$ ). The dotted (red) line shows the regression coefficient obtained when dropping the city of Passaic, NJ (coefficient $=0.940$, standard error $=0.068$ ). 
Figure 7: The impact of immigration on marriage rates, by gender and age groups

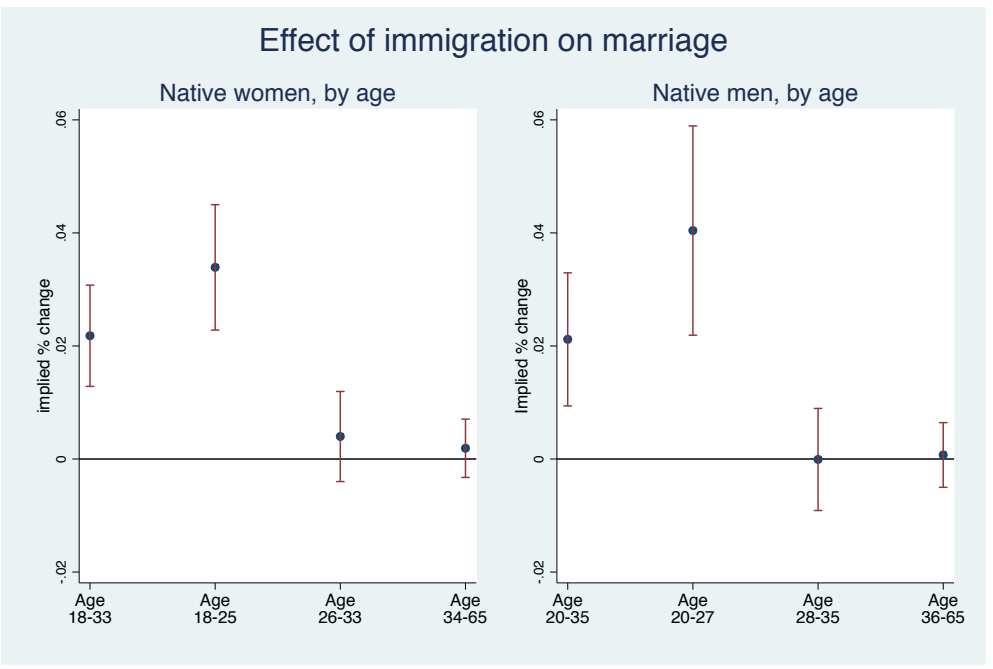

Notes: This graph shows the impact of one standard deviation increase of the fraction of immigrants on the increase in marriage rates with respect to the mean value in 1910 . We report the standardized coefficients by age group and for men and women separately.

Figure 8: Natives' Occupation Mobility (20-35)

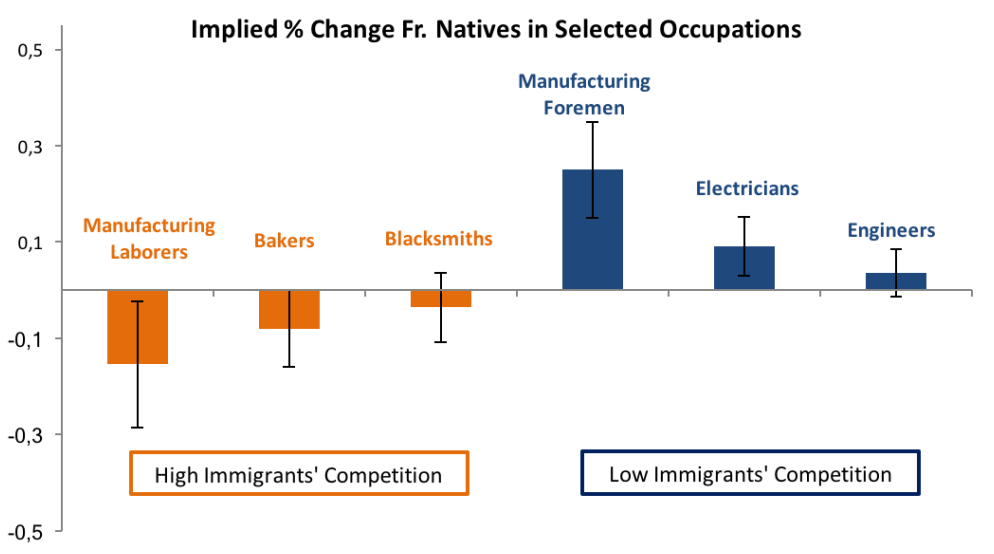

Notes: the figure plots the percent change in the fraction of natives aged 20-35 in each occupation (relative to the 1910 mean) implied by a one standard deviation increase in immigration, according to 2SLS estimates (with corresponding 95\% confidence intervals). 
Figure 9: The impact of immigration on marriage rates, by parentage

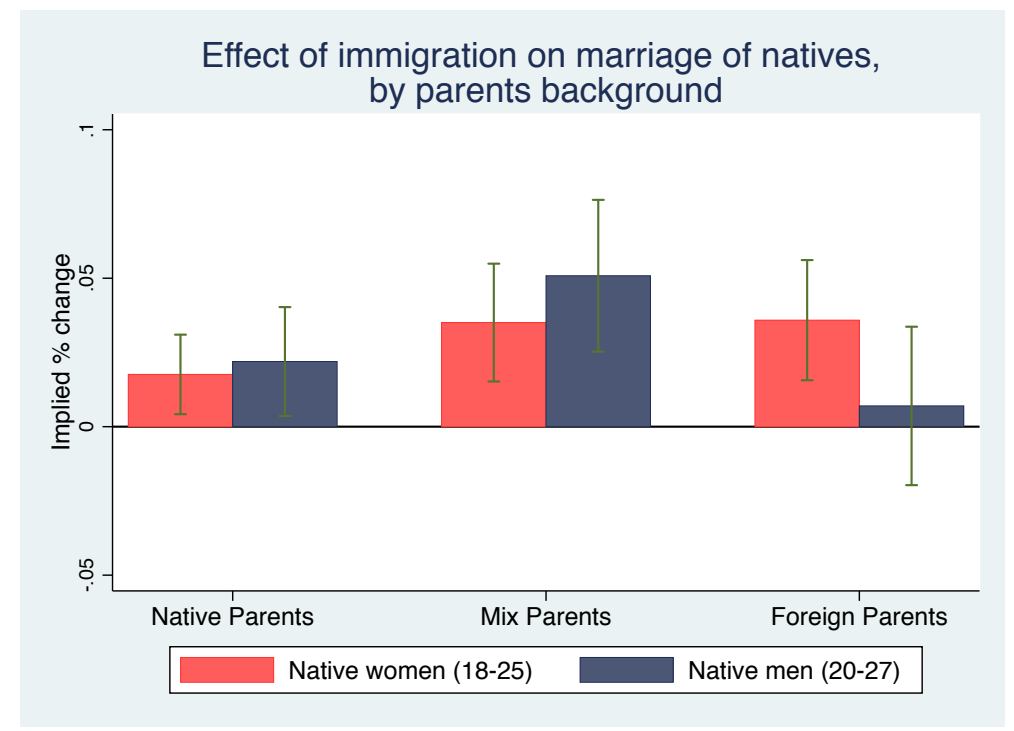

Notes: This graph shows the impact of one standard deviation increase of the fraction of immigrants on the marriage rates of men and women by parentage with respect to the mean value in 1910. We report the standardized coefficients, separately by parentage and gender.

Figure 10: The impact of immigration on labor force participation, by age groups of women

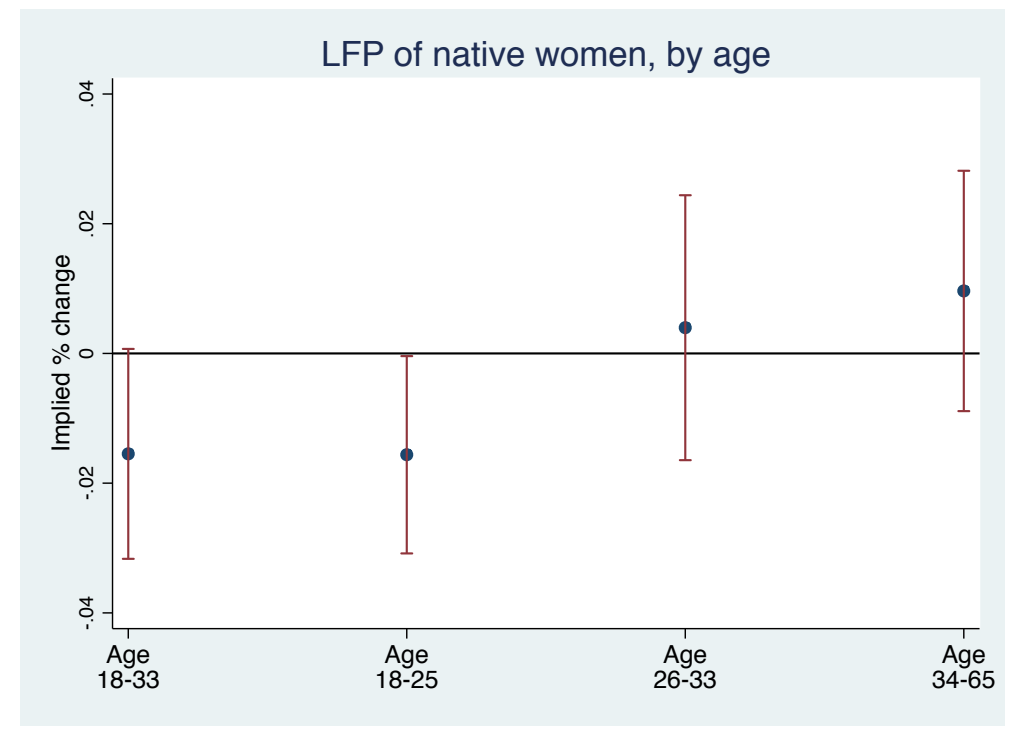

Notes: This graph shows the impact of one standard deviation increase of the fraction of immigrants on the decrease in labor force participation of women with respect to the mean value in 1910. We report the standardized coefficients separately by age group. 
Table 1: Summary Statistics

\begin{tabular}{lccccc}
\hline \hline & Count & Mean & SD & Min & Max \\
\hline Panel A: City Demographics & & & & & \\
\hline Fr. Immigrant & 538 & 0.04 & 0.05 & 0.00 & 0.44 \\
City Population (thousand) & 538 & 190 & 511 & 30 & 6930 \\
\hline \hline Panel B: Key Outcomes & & & & & \\
\hline Marriage Rates of Women & & & & & \\
$\quad$ Aged 18-33 & 538 & 0.49 & 0.08 & 0.28 & 0.67 \\
$\quad$ Aged 18-25 & 538 & 0.35 & 0.08 & 0.12 & 0.58 \\
$\quad$ Aged 26-33 & 538 & 0.65 & 0.07 & 0.46 & 0.81 \\
Marriage Rates of Men & & & & & \\
$\quad$ Aged 20-35 & 538 & 0.47 & 0.07 & 0.18 & 0.65 \\
$\quad$ Aged 20-27 & 538 & 0.31 & 0.07 & 0.11 & 0.49 \\
$\quad$ Aged 28-35 & 538 & 0.65 & 0.07 & 0.26 & 0.81 \\
\hline Fertility of Women 18-33 & & & & & \\
Children to Women Ratio & 538 & 0.65 & 0.12 & 0.40 & 1.00 \\
Mothers to Women Ratio & 538 & 0.34 & 0.05 & 0.21 & 0.49 \\
Children to Mothers Ratio & 538 & 1.90 & 0.11 & 1.59 & 2.27 \\
\hline Living with parents & & & & & \\
$\quad$ Women Aged 18-33 & 538 & 0.36 & 0.09 & 0.17 & 0.58 \\
$\quad$ Men Aged 20-35 & 538 & 0.33 & 0.09 & 0.12 & 0.55 \\
Living in own household & & & & & \\
$\quad$ Women Aged 18-33 & 538 & 0.45 & 0.08 & 0.25 & 0.67 \\
$\quad$ Men Aged 20-35 & 538 & 0.43 & 0.06 & 0.18 & 0.60 \\
\hline \hline
\end{tabular}

Panel C: Labor Market

\begin{tabular}{llllll}
\hline Employment Men 20-35 & 538 & 0.90 & 0.05 & 0.71 & 0.98
\end{tabular}

\begin{tabular}{llllll} 
Labor Force Participation Women 18-33 & 538 & 0.42 & 0.09 & 0.20 & 0.67 \\
\hline \hline
\end{tabular}

Notes: The Table shows the summary statistics of the main variables used in this paper for the 180 US cities with at least 30,000 residents in each Census year report. Source: Authors' calculations using IPUMS data. 
Table 2: Characteristics of husbands of women aged 18-33

\begin{tabular}{|c|c|c|c|c|c|}
\hline \multirow[t]{2}{*}{ "Husband } & \multicolumn{3}{|c|}{ Native } & \multicolumn{2}{|c|}{ Immigrant } \\
\hline & Native Parents & Mix Parents & Foreign Parents & $>10$ years & $\leq 10$ years \\
\hline \multicolumn{6}{|l|}{ Native Wife } \\
\hline Native Parents & 0.73 & 0.07 & 0.13 & 0.06 & 0.02 \\
\hline Mix Parents & 0.50 & 0.12 & 0.24 & 0.11 & 0.03 \\
\hline Foreign Parents & 0.35 & 0.09 & 0.32 & 0.18 & 0.06 \\
\hline \multicolumn{6}{|l|}{ Immigrant Wife } \\
\hline$>10$ years & 0.18 & 0.04 & 0.14 & 0.50 & 0.13 \\
\hline$\leq 10$ years & 0.07 & 0.01 & 0.05 & 0.20 & 0.67 \\
\hline
\end{tabular}


Table 3: First Stage

\begin{tabular}{lcccccc}
\hline & \multicolumn{5}{c}{ Dep. Variable: Fraction of Immigrants } \\
\cline { 2 - 7 } & $(1)$ & $(2)$ & $(3)$ & $(4)$ & $(5)$ & $(6)$ \\
\hline $\mathrm{Z}$ & $0.830^{* * *}$ & $0.944^{* * *}$ & $0.990^{* * *}$ & $0.905^{* * *}$ & $0.889^{* * *}$ & $0.986^{* * *}$ \\
& $(0.053)$ & $(0.071)$ & $(0.063)$ & $(0.090)$ & $(0.086)$ & $(0.066)$ \\
\hline Immigrants over & Actual pop. & 1900 pop. & Predicted pop. & Predicted pop. & Predicted pop. & Predicted pop. \\
Year interacted with 1900 & & & & Immigrants and & Value added by & Fr. native \\
& & & & city population & manufacture & women married \\
\hline F-stat & 249.3 & 175.3 & 251.3 & 100.2 & 107.5 & 224.5 \\
Obs. & 538 & 538 & 538 & 538 & 526 & 538 \\
\hline \hline
\end{tabular}

Notes: the sample includes a balanced panel of the 180 US cities with at least 30,000 residents in each Census year 1910, 1920, and 1930. In Column 1 the actual number of immigrants is scaled by actual population, and the instrument is the leaveout version of the shift-share IV in equation (2) (Section 4.2). Columns 2 and 3 replicate Column 1 by scaling the actual and predicted number of immigrants by, respectively, 1900 and predicted population. From Column 3 onwards, Table 3 presents results from specifications where both the predicted and the actual number of immigrants are scaled by predicted population. Columns 4 to 6 include the interaction between year dummies and, respectively: the (log of) 1900 city and immigrants population; the (log of) 1904 value added by manufacture per establishment; and the marriage rates of native women in 1900. F-stat refers to the K-P F-stat for weak instrument. All regressions partial out city and state by year fixed effects. Robust standard errors, clustered at the MSA level, in parenthesis. ${ }^{*} p<0.10,{ }^{* *} p<0.05,{ }^{* * *} p<0.01$ 
Table 4: Immigration and Marriage of Natives

\begin{tabular}{|c|c|c|c|c|c|c|}
\hline & $\begin{array}{c}\text { (1) } \\
\text { OLS }\end{array}$ & $\begin{array}{c}(2) \\
2 S L S\end{array}$ & $\begin{array}{c}\text { (3) } \\
\text { Pre-trends }\end{array}$ & $\begin{array}{c}(4) \\
2 S L S\end{array}$ & $\begin{array}{c}(5) \\
2 S L S\end{array}$ & $\begin{array}{c}(6) \\
2 S L S\end{array}$ \\
\hline \multicolumn{7}{|c|}{ Panel A: Dep. Var. Marriage Rates of Women (Age 18-33) } \\
\hline Fr. Immigrant & $\begin{array}{c}0.238^{* * *} \\
(0.057)\end{array}$ & $\begin{array}{c}0.209^{* * *} \\
(0.044)\end{array}$ & $\begin{array}{c}0.128 \\
(0.204)\end{array}$ & $\begin{array}{c}0.329^{* * *} \\
(0.058)\end{array}$ & $\begin{array}{c}0.197^{* * *} \\
(0.053)\end{array}$ & $\begin{array}{c}0.154^{* * *} \\
(0.027)\end{array}$ \\
\hline F-stat & & 251.3 & 318.4 & 100.2 & 107.5 & 175.3 \\
\hline Mean dep. var. in 1910 & 0.45 & 0.45 & 0.45 & 0.45 & 0.45 & 0.45 \\
\hline Obs. & 538 & 538 & 178 & 538 & 538 & 538 \\
\hline \multicolumn{7}{|c|}{ Panel B: Dep. Var. Marriage Rates of Men (Age 20-35) } \\
\hline Fr. Immigrant & $\begin{array}{l}-0.006 \\
(0.135)\end{array}$ & $\begin{array}{c}0.190^{* * *} \\
(0.054)\end{array}$ & $\begin{array}{c}0.078 \\
(0.092)\end{array}$ & $\begin{array}{c}0.181^{* * *} \\
(0.059)\end{array}$ & $\begin{array}{c}0.217^{* * *} \\
(0.061)\end{array}$ & $\begin{array}{c}0.121^{* * *} \\
(0.038)\end{array}$ \\
\hline F-stat & & 251.3 & 318.4 & 100.2 & 107.5 & 175.3 \\
\hline Mean dep. var. in 1910 & 0.42 & 0.42 & 0.42 & 0.42 & 0.42 & 0.42 \\
\hline Obs. & 538 & 538 & 178 & 538 & 538 & 538 \\
\hline Pre-period & & & Yes & & & \\
\hline Year by 1900 city & & & & Yes & & \\
\hline \multicolumn{7}{|l|}{ and imm. pop } \\
\hline Year by 1900 fr married & & & & & Yes & \\
\hline Imm over 1900 pop & & & & & & Yes \\
\hline
\end{tabular}

Notes: this Table presents results of OLS and 2SLS for a balanced panel of the 180 US cities with at least 30,000 residents in each Census year report. The dependent variable is the fraction of women married in the age range 18-33 in Panel A and the fraction of men married in the age range 20-35 in Panel B. Fr. Immigrants refers to the fraction of immigrants arrived in the previous decade over predicted city population, and is instrumented using the baseline version of the instrument constructed in Section 4. The mean of dependent variables is shown at the bottom of the Table. Column 3 is a falsification test (pre-trends). In Columns 4 and 5, we check the robustness of our results in column 2, by augmenting our baseline specification interacting year dummies with the (log of) 1900 city and immigrants' population and the 1900 marriage rates, respectively. Finally, in column 6 , we show the robustness of our results scaling both the actual and the predicted number of immigrants by 1900, rather than predicted, population. KP F-stat is the Kleibergen-Paap F stat for joint significance of instruments. All regressions include city and state by year fixed effects. Robust standard errors, clustered at the MSA level, in parenthesis. ${ }^{*} p<0.10,{ }^{* *} p<0.05,{ }^{* * *} p<0.01$ 
Table 5: Immigration and Fertility of Native Women

Dep. Variable: Fertility of Native Women (aged 18-33)

\begin{tabular}{|c|c|c|c|c|c|c|}
\hline & \multicolumn{6}{|c|}{ Dep. Variable: Fertility of Native Women (aged 18-33) } \\
\hline & \multicolumn{2}{|c|}{ Children to Women Ratio } & \multicolumn{2}{|c|}{ Mothers to Women Ratio } & \multicolumn{2}{|c|}{ Children to Mothers Ratio } \\
\hline & All Children & Children $<5$ & All Children & Children $<5$ & All Children & Children $<5$ \\
\hline & (1) & (2) & (3) & (4) & (5) & (6) \\
\hline $\begin{array}{l}\text { Panel A: OLS } \\
\text { Fr. Immigrant }\end{array}$ & $\begin{array}{l}0.291^{* *} \\
(0.131)\end{array}$ & $\begin{array}{c}0.200^{* * *} \\
(0.056)\end{array}$ & $\begin{array}{l}0.132^{* *} \\
(0.052)\end{array}$ & $\begin{array}{c}0.123^{* * *} \\
(0.036)\end{array}$ & $\begin{array}{c}0.149 \\
(0.159)\end{array}$ & $\begin{array}{l}0.209^{* *} \\
(0.085)\end{array}$ \\
\hline $\begin{array}{l}\text { Panel B: } 2 S L S \\
\text { Fr. Immigrant }\end{array}$ & $\begin{array}{c}0.431^{* * *} \\
(0.072)\end{array}$ & $\begin{array}{c}0.194^{* * *} \\
(0.037)\end{array}$ & $\begin{array}{c}0.165^{* * *} \\
(0.027)\end{array}$ & $\begin{array}{c}0.105^{* * *} \\
(0.026)\end{array}$ & $\begin{array}{c}0.342^{* * *} \\
(0.103)\end{array}$ & $\begin{array}{l}0.111^{* *} \\
(0.052)\end{array}$ \\
\hline F-stat & 251.3 & 251.3 & 251.3 & 251.3 & 251.3 & 251.3 \\
\hline Mean Dep.Var. & 0.650 & 0.340 & 0.340 & 0.250 & 1.900 & 1.010 \\
\hline Obs. & 538 & 538 & 538 & 538 & 538 & 538 \\
\hline
\end{tabular}

Notes: this Table presents results of 2SLS for a balanced panel of the 180 US cities with at least 30,000 residents in each Census year report. The dependent variable is: in column 1 (column 2), the total number of children (toddlers) with native mother in the age range 18-33 over the total number of women in the age range 18-33, in column 3 (column 4) the fraction of women in the age range 18-33 who have children (toddlers) and in column 5 (column 6) the average number of children (toddlers) per mother in the age range 18-33. Fr. Immigrants refers to the fraction of immigrants arrived in the previous decade over predicted city population, and is instrumented using the baseline version of the instrument constructed in Section 4.2. The mean of dependent variables is shown at the bottom of the Table. KP F-stat is the Kleibergen-Paap F stat for joint significance of instruments. All regressions include city and state by year fixed effects. Robust standard errors, clustered at the MSA level, in parenthesis. ${ }^{*} p<0.10,{ }^{* *} p<0.05,{ }^{* * *} p<0.01$ 
Table 6: Immigration and Living Choices of Natives

(1)

(2)

(3)

(4)

\begin{tabular}{lccccc}
\hline Dep. Var. & $\begin{array}{c}\text { Living with } \\
\text { Parents }\end{array}$ & $\begin{array}{c}\text { Living in } \\
\text { Own House }\end{array}$ & $\begin{array}{c}\text { Living with } \\
\text { Parents }\end{array}$ & $\begin{array}{c}\text { Living in } \\
\text { Own House }\end{array}$ \\
\cline { 2 - 3 } \cline { 5 - 6 } Panel A: OLS & \multicolumn{2}{c}{ Women 18-33 } & & Men 20-35 \\
\cline { 2 - 3 } \cline { 5 - 6 } Fr. Immigrant & $-0.383^{* * *}$ & $0.231^{* * *}$ & & $-0.493^{* * *}$ & -0.004 \\
& $(0.086)$ & $(0.057)$ & & $(0.131)$ & $(0.137)$ \\
\hline Panel B: $2 S L S$ & & & & \\
Fr. Immigrant & $-0.285^{* * *}$ & $0.204^{* * *}$ & & $-0.316^{* * *}$ & $0.171^{* * *}$ \\
& $(0.043)$ & $(0.040)$ & & $(0.045)$ & $(0.056)$ \\
\hline F-stat & 251.3 & 251.3 & & 251.3 & 251.3 \\
Mean dep. var. & 0.370 & 0.418 & & 0.317 & 0.387 \\
Obs. & 538 & 538 & & 538 & 538 \\
\hline \hline
\end{tabular}

Notes: this Table presents results of OLS and 2SLS for a balanced panel of the 180 US cities with at least 30,000 residents in each Census year report. The dependent variable are described on the top part of the Table. Fr. Immigrants refers to the fraction of immigrants arrived in the previous decade over predicted city population, and is instrumented using the baseline version of the instrument constructed in Section 4.2. The mean of dependent variables is shown at the bottom of the Table. KP F-stat is the Kleibergen-Paap F stat for joint significance of instruments. All regressions include city and state by year fixed effects. Robust standard errors, clustered at the MSA level, in parenthesis. ${ }^{*} p<0.10,{ }^{* *} p<0.05,{ }^{* * *} p<0.01$ 
Table 7: Immigration and Employment of Native Men

Dep. Var. : Natives' Employment to Population Ratio (Men, Age 20-35)

\begin{tabular}{lcccccc}
\hline & $(1)$ & $(2)$ & $(3)$ & $(4)$ & $(5)$ & $(6)$ \\
& OLS & 2SLS & Pre-trends & 2SLS & 2SLS & 2SLS \\
\hline Fr. Immigrant & $0.151^{* * *}$ & $0.152^{* * *}$ & -0.071 & $0.094^{* *}$ & $0.130^{* *}$ & $0.113^{* * *}$ \\
& $(0.043)$ & $(0.044)$ & $(0.124)$ & $(0.041)$ & $(0.053)$ & $(0.033)$ \\
\hline F-stat & & 251.3 & 318.4 & 100.2 & 107.5 & 175.3 \\
Mean dep. var. in 1910 & 0.911 & 0.911 & 0.911 & 0.911 & 0.911 & 0.911 \\
Obs. & 538 & 538 & 180 & 538 & 538 & 538 \\
\hline Pre-period & & & Yes & & & \\
Year by 1900 city and imm. pop & & & & & & Yes \\
Year by 1900 value added manuf. & & & & & & Yes \\
Imm over 1900 pop & & & & & & \\
\hline \hline
\end{tabular}

Notes: this Table presents results of OLS and 2SLS for a balanced panel of the 180 US cities with at least 30,000 residents in each Census year report. The dependent variable is the natives' employment to population ratio in the age range 20-35 for men. Fr. Immigrants refers to the fraction of immigrants arrived in the previous decade over predicted city population, and is instrumented using the baseline version of the instrument constructed in Section 4.2. Column 3 is a falsification test (pre-trends). In Columns 4 and 5, we check the robustness of our results in column 2, by augmenting our baseline specification interacting year dummies with the (log of) 1900 city and immigrants' population and the 1900 value added in manufacture sector, respectively. Finally, in column 6, we show the robustness of our results scaling both the actual and the predicted number of immigrants by 1900 , rather than predicted, population. The mean of dependent variables is shown at the bottom of the Table. KP F-stat is the Kleibergen-Paap F stat for joint significance of instruments. All regressions include city and state by year fixed effects. Robust standard errors, clustered at the MSA level, in parenthesis. ${ }^{*} p<0.10,{ }^{* *} p<0.05,{ }^{* * *} p<0.01$ 
Table 8: Immigration, Marriage Rates, and Fertility of Native Women aged 18-33 (2SLS results)

\begin{tabular}{|c|c|c|c|c|c|c|}
\hline & (1) & (2) & (3) & (4) & $(5)$ & (6) \\
\hline & \multicolumn{3}{|c|}{ All Native Women } & \multicolumn{3}{|c|}{ Second Generation Women } \\
\hline Husband & All & Native Parentage & Immigrant & All & Native Parentage & Immigrant \\
\hline \multicolumn{7}{|c|}{ Panel A: Marriage rates } \\
\hline Fr. Immigrant & $\begin{array}{c}0.209^{* * *} \\
(0.044)\end{array}$ & $\begin{array}{c}0.309^{* * *} \\
(0.046)\end{array}$ & $\begin{array}{c}0.001 \\
(0.020)\end{array}$ & $\begin{array}{c}0.193^{* * *} \\
(0.071)\end{array}$ & $\begin{array}{l}0.169^{* *} \\
(0.066)\end{array}$ & $\begin{array}{c}0.178^{* * *} \\
(0.046)\end{array}$ \\
\hline Mean dep. var. & 0.47 & 0.27 & 0.04 & 0.45 & 0.14 & 0.10 \\
\hline \multicolumn{7}{|c|}{ Panel B: Fertility (Children to Women Ratio) } \\
\hline Fr. Immigrant & $\begin{array}{c}0.431^{* * *} \\
(0.072)\end{array}$ & $\begin{array}{c}0.443^{* * *} \\
(0.087)\end{array}$ & $\begin{array}{l}-0.005 \\
(0.053)\end{array}$ & $\begin{array}{c}0.359^{* *} \\
(0.162)\end{array}$ & $\begin{array}{l}0.177^{*} \\
(0.103)\end{array}$ & $\begin{array}{l}0.259^{* *} \\
(0.127)\end{array}$ \\
\hline Mean dep. var. & 0.65 & 0.35 & 0.07 & 0.58 & 0.19 & 0.17 \\
\hline F-stat & 251.3 & 251.3 & 251.3 & 251.3 & 251.3 & 251.3 \\
\hline Obs. & 538 & 538 & 538 & 538 & 538 & 538 \\
\hline
\end{tabular}

Notes: this Table presents results of 2SLS for a balanced panel of the 180 US cities with at least 30,000 residents in each Census year report. In panel A, the dependent variable is the marriage rates of women aged 1833 by husband parentage. In panel B, the dependent variable is the children to women ratio by father parentage. We consider only children of women aged 18-33. For example, in column 2 of Panel B, the dependent variable is the number of children with native mother aged 18-33 and father with a native parentage over the number of native women aged 18-33. Columns 4-6 focus on women who are second generation immigrants. Fr. Immigrants refers to the fraction of immigrants arrived in the previous decade over predicted city population, and is instrumented using the baseline version of the instrument constructed in Section 4.2. The mean of dependent variables is shown at the bottom of the Table. KP F-stat is the Kleibergen-Paap F stat for joint significance of instruments. All regressions include city and state by year fixed effects. Robust standard errors, clustered at the MSA level, in parenthesis. ${ }^{*} p<0.10,{ }^{* *} p<0.05,{ }^{* * *} p<0.01$ 
Table 9: Immigration, Linguistic Distance, Employment and Marriage Rates of Natives (2SLS results)

\begin{tabular}{|c|c|c|c|c|c|}
\hline \multirow{2}{*}{$\begin{array}{l}\text { Dep Var.: } \\
\text { Own Parents }\end{array}$} & \multirow{2}{*}{$\begin{array}{c}\text { Employment Men 20-35 } \\
\text { (1) }\end{array}$} & \multicolumn{4}{|c|}{ Marriage Rate Women 18-33 } \\
\hline & & $\begin{array}{l}\text { All } \\
(2)\end{array}$ & $\begin{array}{c}\text { Native } \\
\text { (3) }\end{array}$ & $\begin{array}{c}\text { Mix } \\
(4)\end{array}$ & $\begin{array}{c}\text { Immigrants } \\
(5)\end{array}$ \\
\hline Fr. Immigrant & $\begin{array}{l}0.136^{* *} \\
(0.066)\end{array}$ & $\begin{array}{c}0.207^{* * *} \\
(0.060)\end{array}$ & $\begin{array}{l}0.126^{* *} \\
(0.064)\end{array}$ & $\begin{array}{c}0.282^{* * *} \\
(0.091)\end{array}$ & $\begin{array}{c}0.274^{* * *} \\
(0.102)\end{array}$ \\
\hline Ling. Distance & $\begin{array}{c}0.001 \\
(0.004)\end{array}$ & $\begin{array}{c}0.000 \\
(0.003)\end{array}$ & $\begin{array}{c}0.001 \\
(0.004)\end{array}$ & $\begin{array}{l}-0.004 \\
(0.005)\end{array}$ & $\begin{array}{l}-0.007 \\
(0.006)\end{array}$ \\
\hline Mean Dep. Var. & 0.340 & 0.257 & 0.277 & 0.642 & 0.603 \\
\hline Obs. & 538 & 538 & 538 & 538 & 538 \\
\hline
\end{tabular}

Notes: this Table presents results of 2SLS for a balanced panel of the 180 US cities with at least 30,000 residents in each Census year report. The dependent variable is the marriage rate of the groups describled in each panel. Fr. Immigrants refers to the fraction of immigrants arrived in the previous decade over predicted city population, and is instrumented using the baseline version of the instrument constructed in Section 4.2. The mean of dependent variables is shown at the bottom of the Table. KP F-stat is the Kleibergen-Paap F stat for joint significance of instruments. All regressions include city and state by year fixed effects. Robust standard errors, clustered at the MSA level, in parenthesis. ${ }^{*} p<0.10,{ }^{* *} p<0.05,{ }^{* * *} p<0.01$ 


\title{
Appendix for Online Pubblication
}

\author{
Happily Ever After: \\ Immigration, Natives' Marriage, and Fertility \\ Michela Carlana* Marco Tabellini ${ }^{\dagger}$
}

July 2018

*Harvard Kennedy School (e-mail: michela_carlana@hks.harvard.edu).

†Harvard Business School (e-mail: mtabellini@hbs.edu). 


\section{A Additional Tables and Figures}

Figure A.1: Summary Statistics on share of men and sex ratios for natives and immigrants (in 1910)

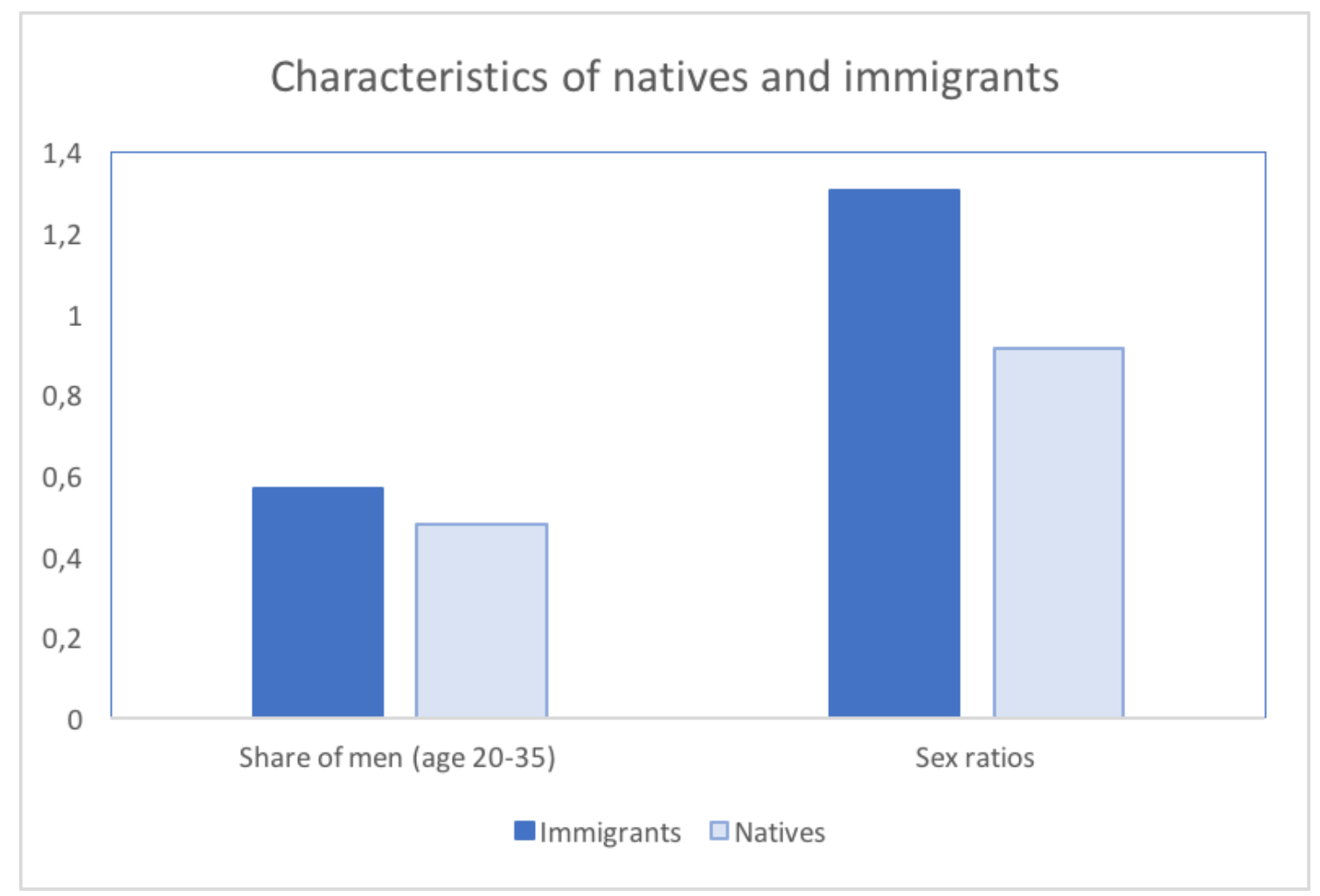

Notes: The sex ratios is defined as the number of native men (resp. immigrant men) in the age group 20-35 over the number of native women in the age group 18-33 (resp. immigrant women). Source: Authors' calculations from IPUMS sample of 1910 US Census (Ruggles et al., 2015). 
Figure A.2: Total Number of Immigrants (in Thousands)

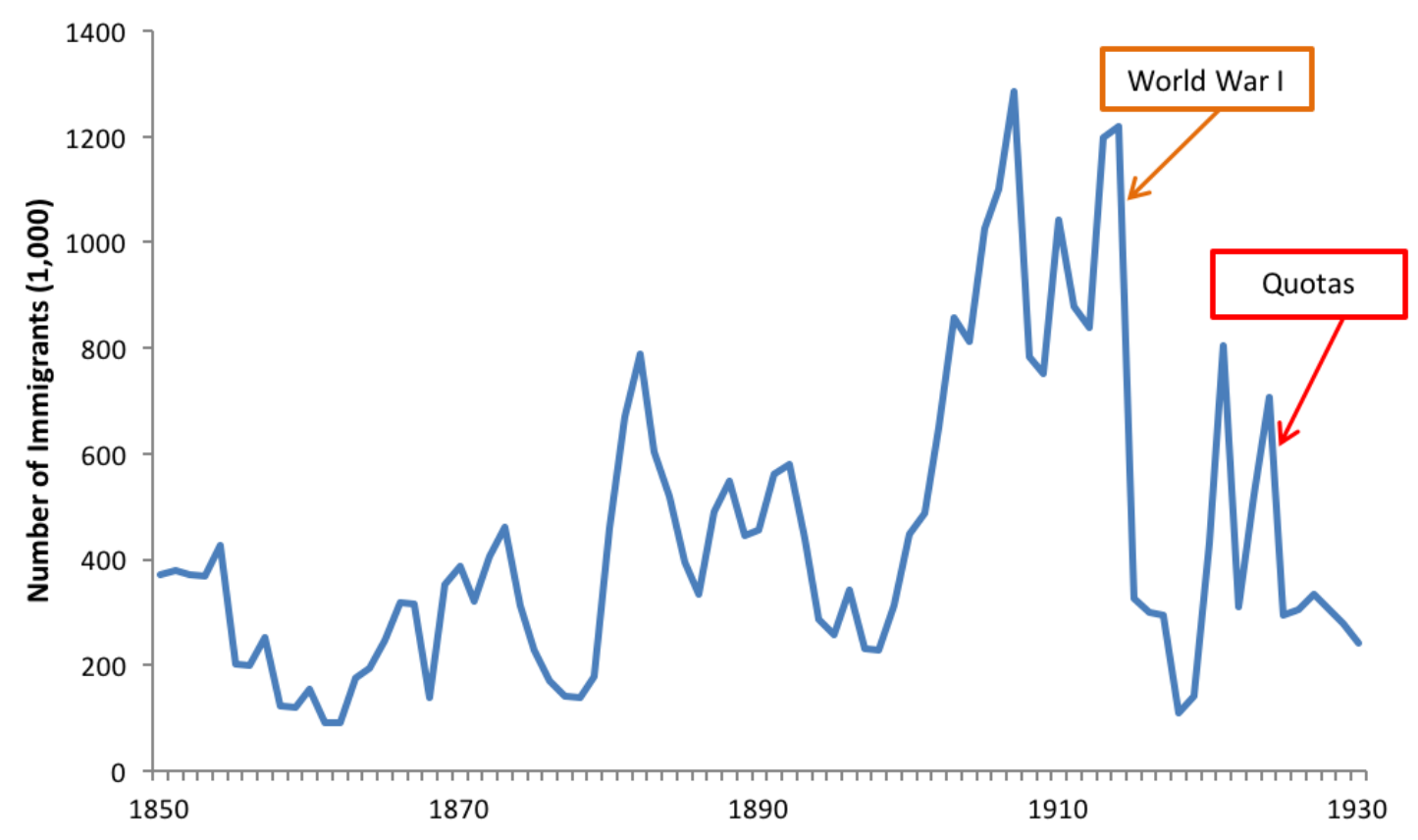

Notes: Annual inflow of immigrants to the United States (1850-1930). Source: Migration Policy Institute. 
Figure A.3: Recent Immigrants Over 1900 City Population, by Decade

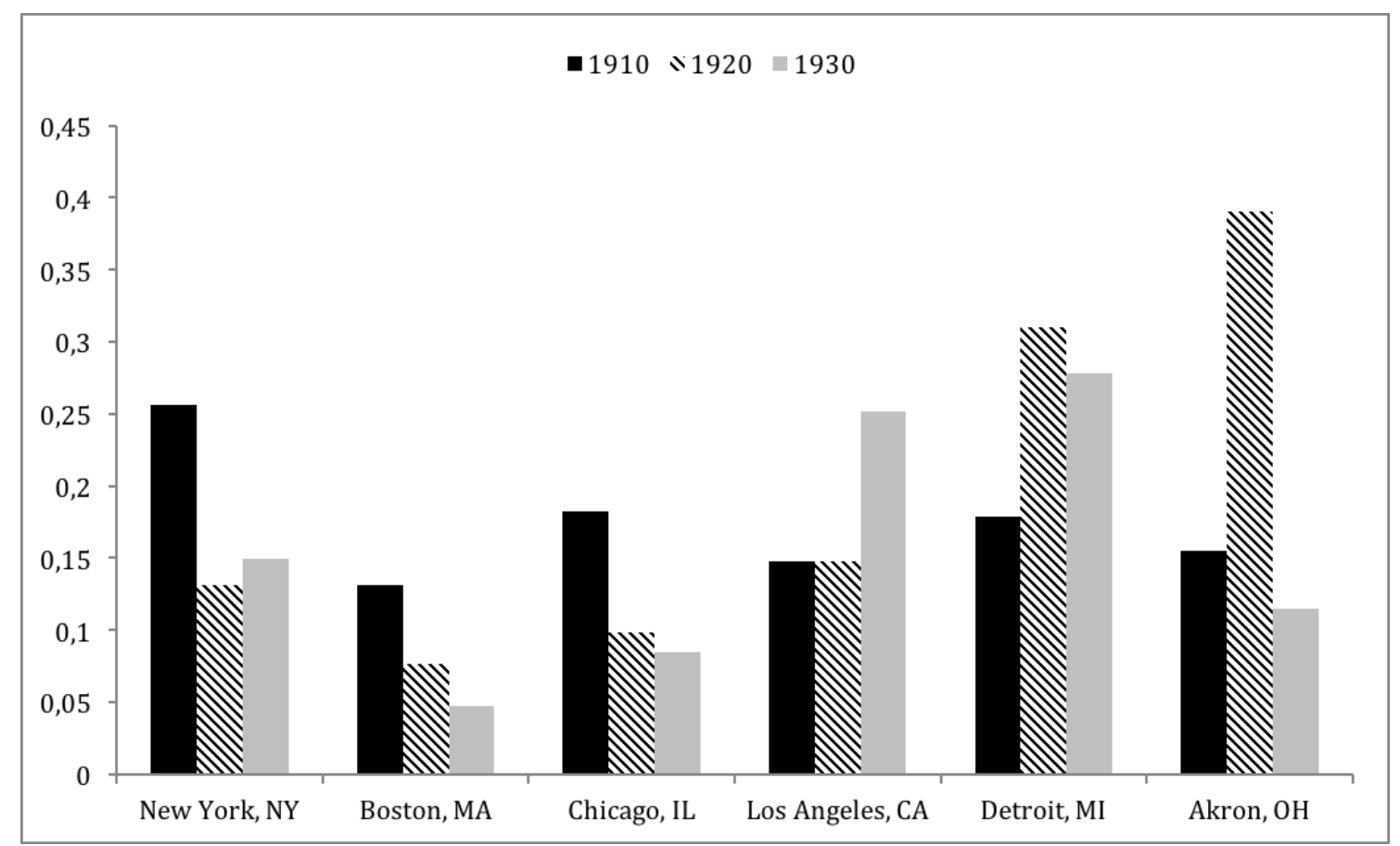

Notes: Number of European immigrants that arrived in the United States in the last decade over 1900 city population, for selected cities and by decade. Source: Authors' calculations from IPUMS sample of US Census (Ruggles et al., 2015). 
Figure A.4: 180 Cities in the Balanced Panel.

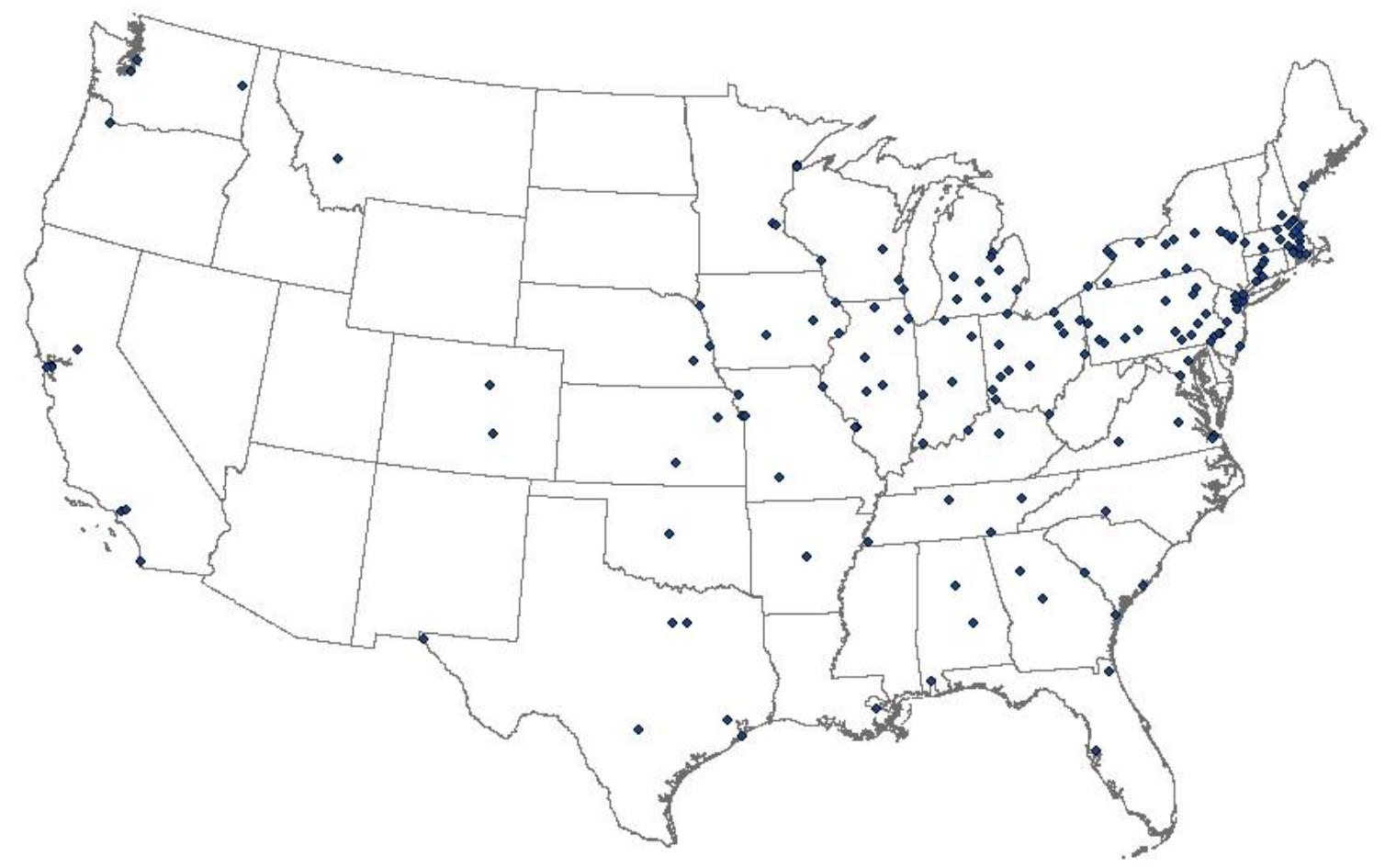

Notes: The map plots the 180 cities with at least 30,000 residents in each of the three Census years 1910, 1920, and 1930. 
Figure A.5: Share of Immigrants from Selected Regions in Ohio, 1900

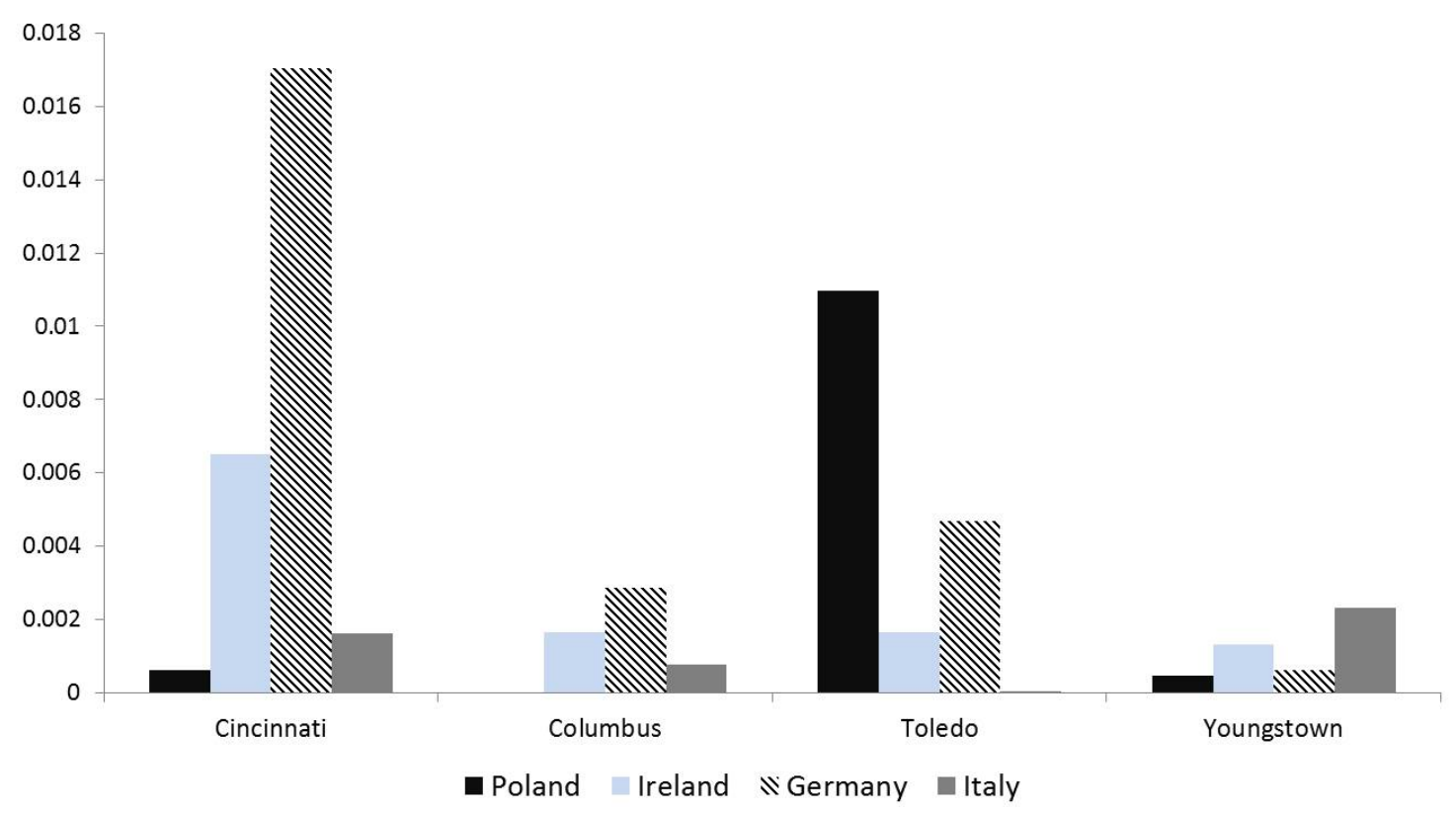

Notes: This graph shows share of individuals of European ancestry living in selected cities of Ohio in 1900, for selected ethnic groups. Source: Authors' calculations using IPUMS data. . 
Figure A.6: The impact of immigration on the choice of creating an independent family unit, by gender and age group.

\section{Effect of immigration on the living choice: own household}
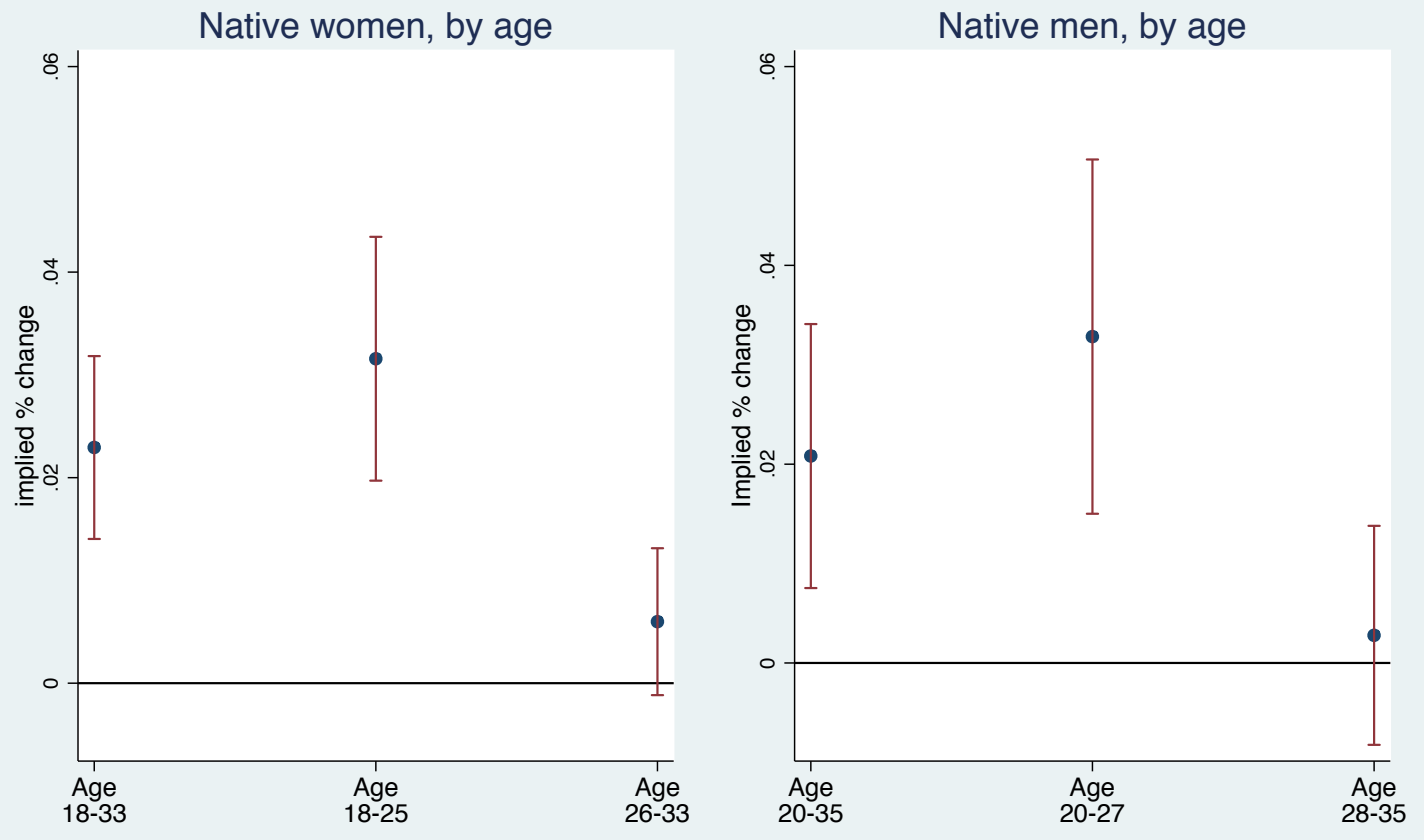

Notes: This graph shows the impact of one standard deviation increase of the fraction of immigrants on the probability of being the household head or spouse by age and gender. 
Figure A.7: The impact of immigration on the employment of native men by age groups and gender

\section{Employment of native men, by age}

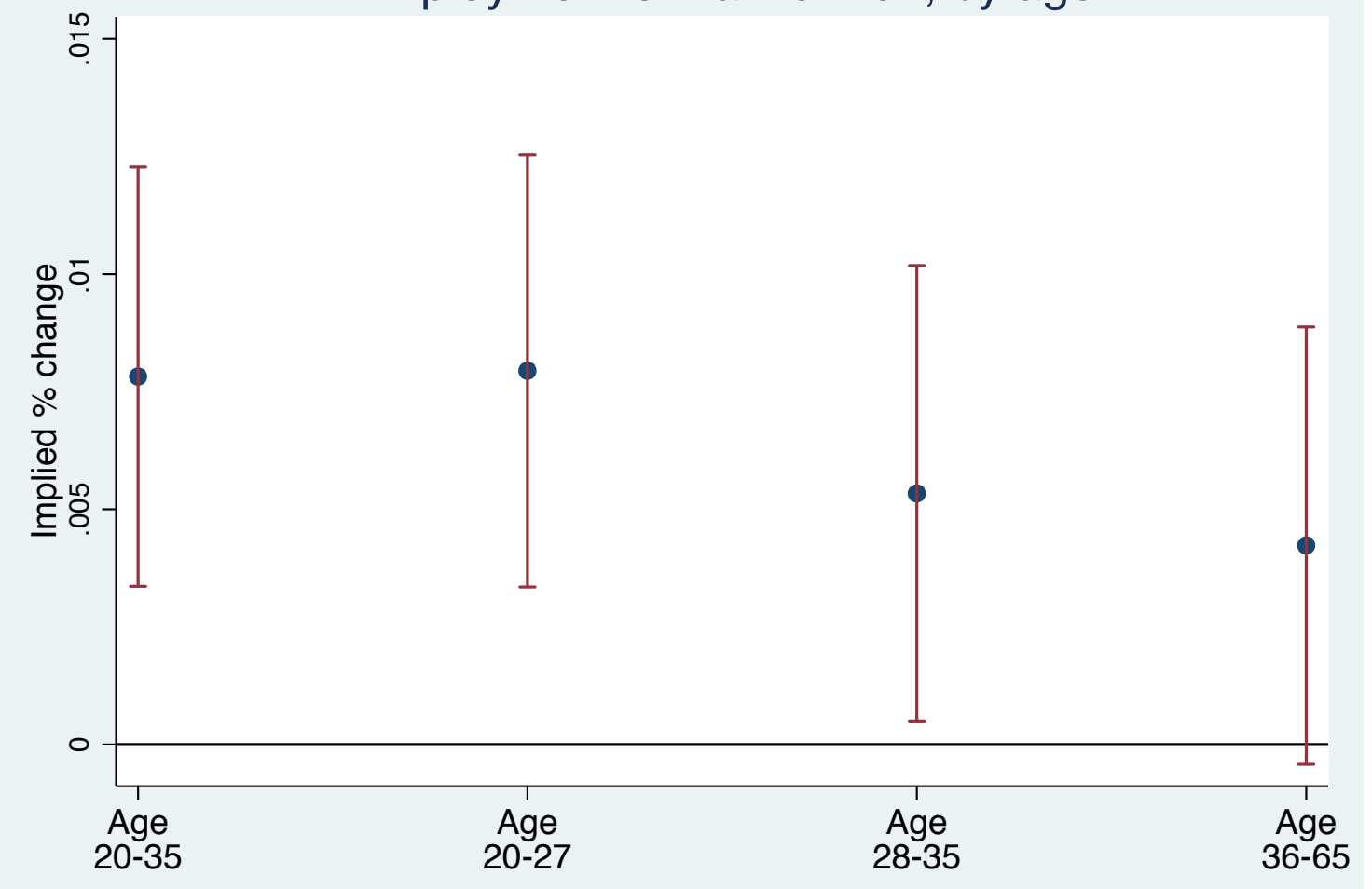

Notes: This graph shows the impact of one standard deviation increase of the fraction of immigrants on the increase in the probability of employment for native men with respect to the mean value in 1910 . We report the standardized coefficients separately by age group. 
Figure A.8: The impact of immigration on the marriage rate of native women (age 18-33), by group.

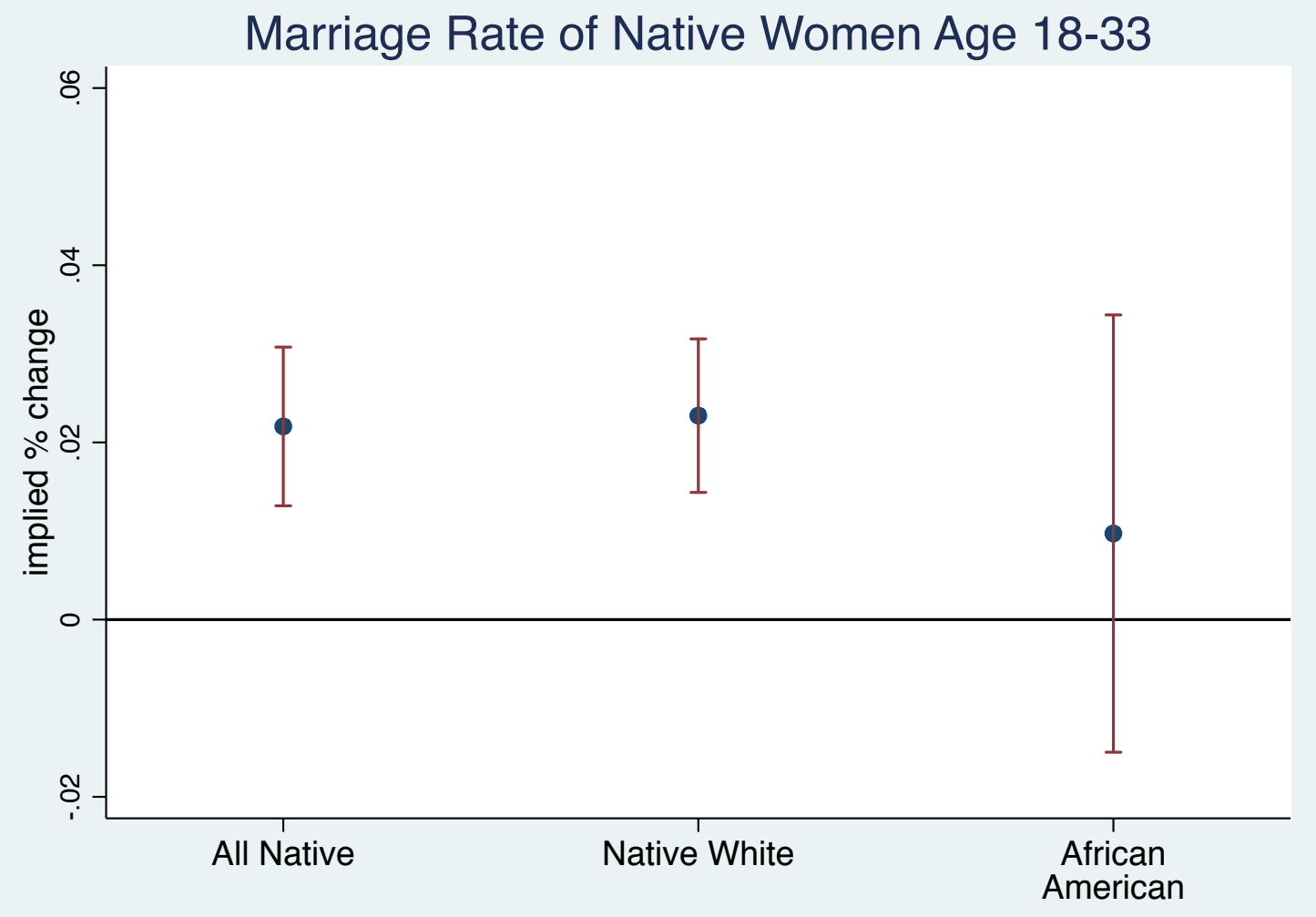

Notes: This graph shows the impact of one standard deviation increase of the fraction of immigrants on the marriage rate of all native women 18-33, native white and African American. 
Figure A.9: The impact of immigration on industrialization

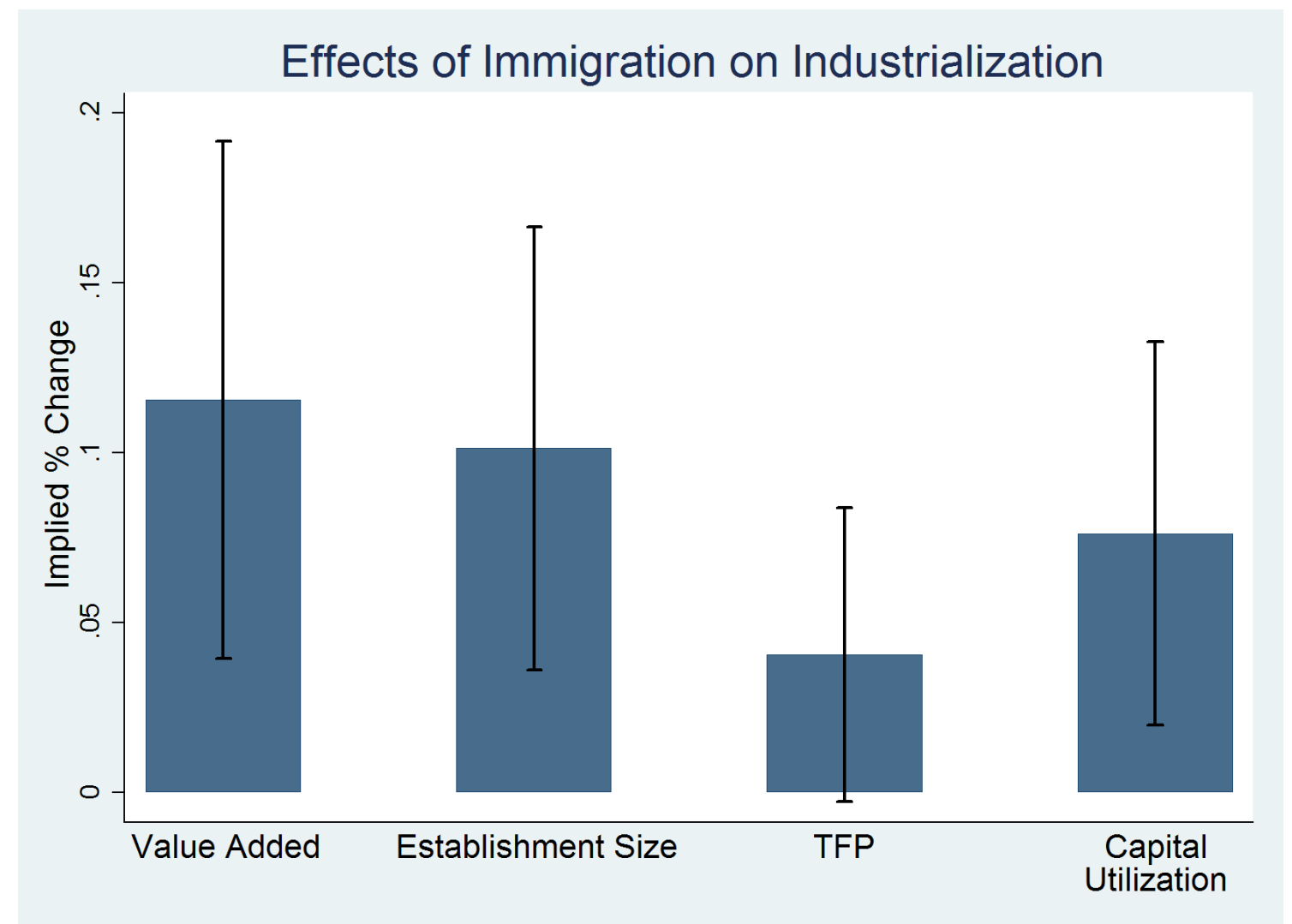

Notes: The figure plots the percent change (with corresponding 95\% confidence intervals) in each of the variables listed above implied by a 5 percentage point (equivalent to a one standard deviation) increase in immigration. Value Added refers to the log of value added per establishment. TFP refers to total factor productivity, and was constructed assuming a Cobb-Douglas production function with two factors of production, capital and homogenous labor. Capital Utilization is measured as the log of horsepower (equivalent results hold when using horsepower per establishment). 
Figure A.10: The impact of immigration on sex ratios of young adults, by parentage.

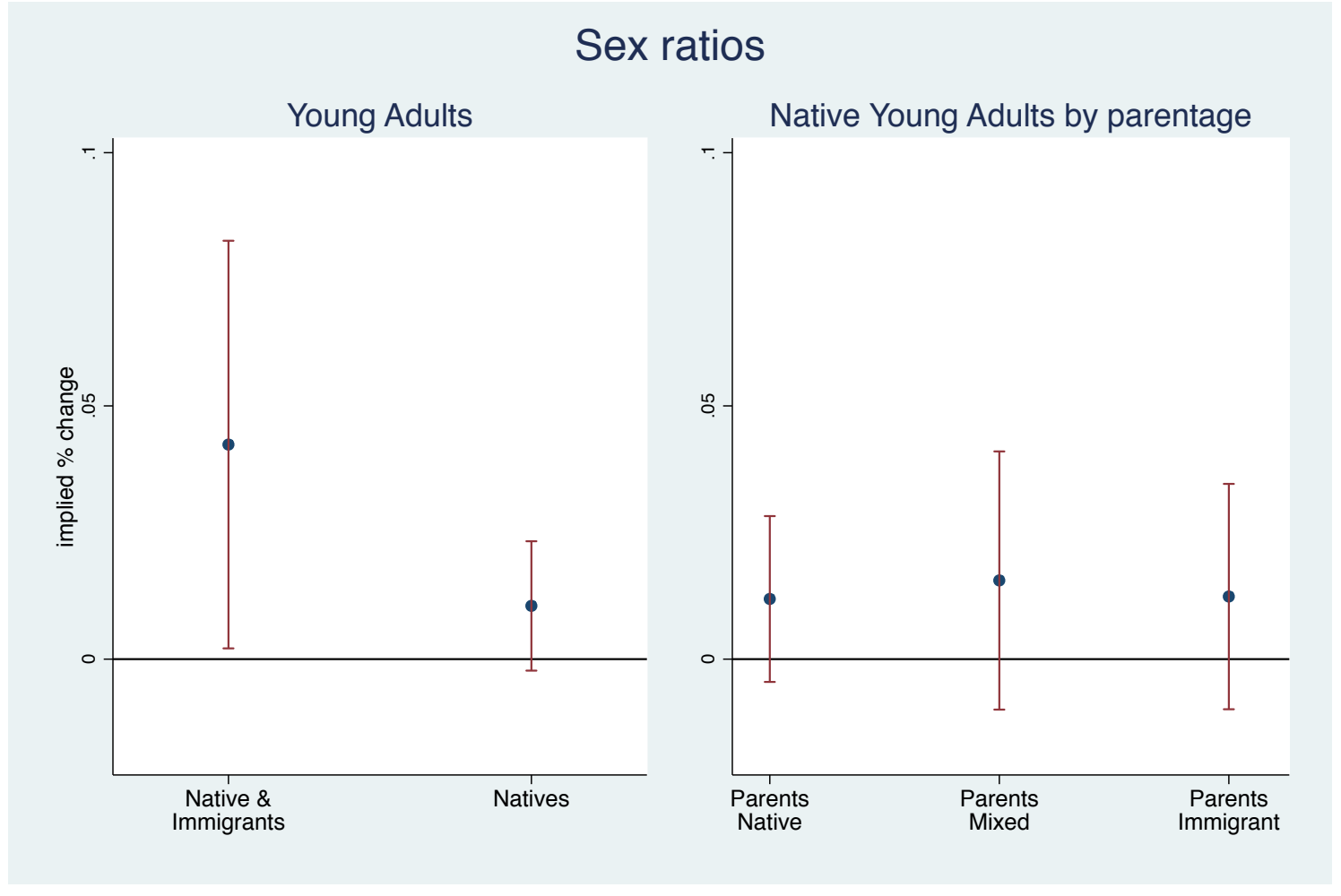

Notes: This graph shows the impact of one standard deviation increase of the fraction of immigrants on the sex ratios or young adults, i.e. the number of men in the age group 20-35 over the number of women in the age group 18-33. The first bar shows the impact for the whole population (natives+ immigrants) living in the 180 US cities with at least 30,000 residents in each Census year. The following bars present the sex ratios for natives, divided by parentage.

Table A.1: Sending Regions

\begin{tabular}{lc}
\hline UK & Russia \\
Ireland & Eastern Europe (Yugoslavia, Czechoslovakia, etc.) \\
Denmark & Austria-Hungary \\
Finland & Switzerland \\
Norway & France \\
Sweden & Belgium-Netherlands \\
Germany & Greece-Portugal-Spain \\
Poland & Italy \\
\hline \hline
\end{tabular}


Table A.2: The impact of immigration on marriage rates by parentage

\begin{tabular}{|c|c|c|c|}
\hline Akron, $\mathrm{OH}$ & Elizabeth, NJ & McKeesport, PA & Saint Joseph, MO \\
\hline Albany, NY & Elmira, NY & Memphis, TN & Saint Louis, MO \\
\hline Allentown, PA & Erie, PA & Milwaukee, WI & Saint Paul, MN \\
\hline Altoona, PA & Evansville, IN & Minneapolis, MN & Salem, MA \\
\hline Amsterdam, NY & Everett, MA & Mobile, AL & San Antonio, TX \\
\hline Atlanta, GA & Fall River, MA & Montgomery, AL & San Diego, CA \\
\hline Atlantic City, NJ & Fitchburg, MA & Mount Vernon, NY & San Francisco, CA \\
\hline Auburn, NY & Flint, MI & Nashville, TN & Savannah, GA \\
\hline Augusta, GA & Fort Wayne, IN & New Bedford, MA & Schenectedy, NY \\
\hline Baltimore, MD & Fort Worth, TX & New Britain, CT & Scranton, PA \\
\hline Bay City, MI & Galveston, TX & New Castle, PA & Seattle, WA \\
\hline Bayonne, NJ & Grand Rapids, MI & New Haven, CT & Sioux City, IA \\
\hline Berkeley, CA & Hamilton, $\mathrm{OH}$ & New Orleans, LA & Somerville, MA \\
\hline Binghamton, NY & Harrisburg, PA & New York, NY & South Bend, IN \\
\hline Birmingham, AL & Hartford, CT & Newark, NJ & Spokane, WA \\
\hline Boston, MA & Haverhill, MA & Newton, MA & Springfield, IL \\
\hline Bridgeport, CT & Hoboken, NJ & Niagara Falls, NY & Springfield, MA \\
\hline Brockton, MA & Holyoke, MA & Norfolk, VA & Springfield, MO \\
\hline Buffalo, NY & Houston, TX & Oakland, CA & Springfield, $\mathrm{OH}$ \\
\hline Butte, MT & Huntington, WV & Oklahoma City, OK & Superior, WI \\
\hline Cambridge, MA & Indianapolis, IN & Omaha, NE & Syracuse, NY \\
\hline Camden, NJ & Jackson, MI & Oshkosh, WI & Tacoma, WA \\
\hline Canton, $\mathrm{OH}$ & Jacksonville, FL & Pasadena, CA & Tampa, FL \\
\hline Cedar Rapids, IA & Jamestown, NY & Passaic, NJ & Taunton, MA \\
\hline Charleston, SC & Jersey City, NJ & Paterson, NJ & Terre Haute, IN \\
\hline Charlotte, NC & Johnstown, PA & Pawtucket, RI & Toledo, $\mathrm{OH}$ \\
\hline Chattanooga, TN & Joliet, IL & Peoria, IL & Topeka, KS \\
\hline Chelsea, MA & Kalamazoo, MI & Perth Amboy, NJ & Trenton, NJ \\
\hline Chester, PA & Kansas City, KS & Philadelphia, PA & Troy, NY \\
\hline Chicago, IL & Kansas City, MO & Pittsburgh, PA & Utica, NY \\
\hline Cincinnati, OH & Knoxville, TN & Pittsfield, MA & Washington, DC \\
\hline Cleveland, $\mathrm{OH}$ & La Crosse, WI & Portland, ME & Waterbury, CT \\
\hline Columbus, $\mathrm{OH}$ & Lancaster, PA & Portland, OR & Wheeling, WV \\
\hline Covington, $\mathrm{KY}$ & Lansing, MI & Portsmouth, VA & Wichita, KS \\
\hline Dallas, TX & Lawrence, MA & Providence, RI & Wilkes-Barre, PA \\
\hline Davenport, IA & Lexington, $\mathrm{KY}$ & Pueblo, $\mathrm{CO}$ & Williamsport, PA \\
\hline Dayton, $\mathrm{OH}$ & Lima, $\mathrm{OH}$ & Quincy, IL & Wilmington, DE \\
\hline Decatur, IL & Lincoln, NE & Quincy, MA & Woonsocket, RI \\
\hline Denver, CO & Little Rock, AR & Racine, WI & Worcester, MA \\
\hline Des Moines, IA & Los Angeles, CA & Reading, PA & Yonkers, NY \\
\hline Detroit, MI & Louisville, KY & Richmond, VA & York, PA \\
\hline Dubuque, IA & Lowell, MA & Roanoke, VA & Youngstown, $\mathrm{OH}$ \\
\hline Duluth, MN & Lynn, MA & Rochester, NY & \\
\hline East Orange, NJ & Macon, GA & Rockford, IL & \\
\hline East St. Louis, IL & Malden, MA & Sacramento, CA & \\
\hline El Paso, TX & Manchester, NH & Saginaw, MI & \\
\hline
\end{tabular}

Notes: This table lists the 180 US cities with at least 30,000 residents in each Census year. 
Table A.3: Immigration and Marriage of Native Men aged 20-35

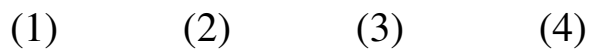

Dep. Var.: Marriage rates of men aged 20-35

\begin{tabular}{lccccc}
\hline & \multicolumn{2}{c}{ All Sample } & & \multicolumn{2}{c}{ Restricted Sample } \\
& OLS & 2SLS & & OLS & 2SLS \\
\cline { 2 - 3 } \cline { 5 - 6 } Fr. Immigrant & -0.006 & $0.190^{* * *}$ & & 0.077 & $0.147^{* *}$ \\
& $(0.135)$ & $(0.054)$ & & $(0.082)$ & $(0.063)$ \\
\hline F-stat & & 251.3 & & 251.3 \\
Mean dep. var. in 1910 & 0.42 & 0.42 & & 0.43 & 0.43 \\
Obs. & 538 & 538 & & 529 & 529 \\
\hline \hline
\end{tabular}

Notes: this Table presents results of OLS and 2SLS for a balanced panel of the 180 US cities with at least 30,000 residents in each Census year report in columns 1 and 2. In columns 3 and 4, we exclude three cities (Duluth, Superior, and Tacoma) with an extraordinary low level of marriage rates of men aged 20-35 in 1910. The dependent variable is the fraction of men married in the age range 20-35. Fr. Immigrants refers to the fraction of immigrants arrived in the previous decade over predicted city population, and is instrumented using the baseline version of the instrument constructed in Section 4. The mean of dependent variables is shown at the bottom of the Table. KP F-stat is the Kleibergen-Paap F stat for joint significance of instruments. All regressions include city and state by year fixed effects. Robust standard errors, clustered at the MSA level, in parenthesis. * $p<0.10,{ }^{* *} p<0.05,{ }^{* * *} p<0.01$ 
Table A.4: Immigration and Marriage of Natives - 2SLS results

(1)

(2)

(3)

(4)

(5)

\begin{tabular}{|c|c|c|c|c|c|}
\hline \multicolumn{6}{|c|}{ Panel A: Women } \\
\hline \multirow[b]{2}{*}{ Age Groups } & \multicolumn{4}{|c|}{ Marriage rates } & \multirow{2}{*}{$\begin{array}{c}\text { Never Married } \\
34-65\end{array}$} \\
\hline & $18-33$ & $18-25$ & $26-33$ & $34-65$ & \\
\hline Fr. Immigrant & $\begin{array}{c}0.209^{* * *} \\
(0.044)\end{array}$ & $\begin{array}{c}0.229^{* * *} \\
(0.038)\end{array}$ & $\begin{array}{c}0.053 \\
(0.054)\end{array}$ & $\begin{array}{c}0.025 \\
(0.035)\end{array}$ & $\begin{array}{c}-0.082^{* * *} \\
(0.019)\end{array}$ \\
\hline Mean dep. var. & 0.47 & 0.34 & 0.65 & 0.63 & 0.15 \\
\hline Obs. & 538 & 538 & 538 & 538 & 538 \\
\hline
\end{tabular}

Panel B: Men

\begin{tabular}{lcccccc}
\hline & \multicolumn{5}{c}{ Marriage rates } & \multirow{2}{*}{ Never Married } \\
Age Groups & $\mathbf{2 0 - 3 5}$ & $\mathbf{2 0 - 2 7}$ & $\mathbf{2 8 - 3 5}$ & $\mathbf{3 6 - 6 5}$ & & $\mathbf{3 6 - 6 5}$ \\
\cline { 2 - 5 } \cline { 5 - 6 } Fr. Immigrant & $0.190^{* * *}$ & $0.236^{* * *}$ & -0.001 & 0.011 & & -0.026 \\
& $(0.054)$ & $(0.055)$ & $(0.059)$ & $(0.045)$ & & $(0.035)$ \\
\cline { 2 - 5 } Mean dep. var. & 0.45 & 0.30 & 0.65 & 0.73 & & 0.14 \\
Obs. & 538 & 538 & 538 & 538 & & 538 \\
\hline \hline
\end{tabular}

Notes: this Table presents results of 2SLS for a balanced panel of the 180 US cities with at least 30,000 residents in each Census year report. The dependent variable is the fraction of women married in the different age range in Panel A and the fraction of men married in the different age range in Panel B. Fr. Immigrants refers to the fraction of immigrants arrived in the previous decade over predicted city population, and is instrumented using the baseline version of the instrument constructed in Section 4.2. The mean of dependent variables is shown at the bottom of the Table. All regressions include city and state by year fixed effects. Robust standard errors, clustered at the MSA level, in parenthesis. ${ }^{*} p<0.10,{ }^{* *} p<0.05,{ }^{* * *} p<0.01$ 
Table A.5: Immigration and Fertility of Native Women - 2SLS results

\begin{tabular}{|c|c|c|c|c|c|c|}
\hline & \multicolumn{6}{|c|}{ Dep. Variable: Fertility of Native Women } \\
\hline & \multicolumn{2}{|c|}{ Children to Women Ratio } & \multicolumn{2}{|c|}{ Mothers to Women Ratio } & \multicolumn{2}{|c|}{ Children to Mothers Ratio } \\
\hline & Age $18-25$ & Age 26-33 & Age $18-25$ & Age 26-33 & Age $18-25$ & Age 26-33 \\
\hline & (1) & (2) & (3) & (4) & $(5)$ & (6) \\
\hline Fr. Immigrant & $\begin{array}{c}0.234^{* * *} \\
(0.049)\end{array}$ & $\begin{array}{c}0.357^{* * *} \\
(0.122)\end{array}$ & $\begin{array}{c}0.131^{* * *} \\
(0.025)\end{array}$ & $\begin{array}{c}0.071^{* *} \\
(0.034)\end{array}$ & $\begin{array}{l}0.160^{* *} \\
(0.080)\end{array}$ & $\begin{array}{c}0.391^{\text {*** }} \\
(0.137)\end{array}$ \\
\hline F-stat & 251.3 & 251.3 & 251.3 & 251.3 & 251.3 & 251.3 \\
\hline Mean Dep.Var. & 0.330 & 1.050 & 0.210 & 0.500 & 1.530 & 2.090 \\
\hline Obs. & 538 & 538 & 538 & 538 & 538 & 538 \\
\hline
\end{tabular}

Notes: this Table presents results of 2SLS for a balanced panel of the 180 US cities with at least 30,000 residents in each Census year report. The dependent variable is: in column 1 and 2, the total number of children with native mother over the total number of women in the age range, in column 3 and 4 the fraction of women who have children and in column 5 and 6 the average number of children per mother. Fr. Immigrants refers to the fraction of immigrants arrived in the previous decade over predicted city population, and is instrumented using the baseline version of the instrument constructed in Section 4.2. The mean of dependent variables is shown at the bottom of the Table. KP F-stat is the Kleibergen-Paap $F$ stat for joint significance of instruments. All regressions include city and state by year fixed effects. Robust standard errors, clustered at the MSA level, in parenthesis. ${ }^{*} p<0.10,{ }^{* *} p<0.05,{ }^{* * *} p<0.01$ 
Table A.6: Native Men (20-35) in Selected Occupations

\begin{tabular}{|c|c|c|c|c|c|c|}
\hline \multirow[b]{2}{*}{ Fraction Natives } & \multicolumn{3}{|c|}{ High Immigrants' Competition } & \multicolumn{3}{|c|}{ Low Immigrants' Competition } \\
\hline & $\begin{array}{c}\text { (1) } \\
\text { Manuf. Laborers }\end{array}$ & $\begin{array}{c}(2) \\
\text { Bakers }\end{array}$ & $\begin{array}{c}(3) \\
\text { Blacksmiths }\end{array}$ & $\begin{array}{c}\text { (4) } \\
\text { Manuf. Foremen }\end{array}$ & $\begin{array}{c}(5) \\
\text { Engineers }\end{array}$ & $\begin{array}{c}(6) \\
\text { Electricians }\end{array}$ \\
\hline $\begin{array}{l}\text { Panel A: OLS } \\
\text { Fr. Immigrant }\end{array}$ & $\begin{array}{l}-0.079 \\
(0.058)\end{array}$ & $\begin{array}{l}-0.008^{*} \\
(0.004)\end{array}$ & $\begin{array}{l}-0.009 \\
(0.005)\end{array}$ & $\begin{array}{c}0.025^{* * *} \\
(0.004)\end{array}$ & $\begin{array}{c}0.017 \\
(0.014)\end{array}$ & $\begin{array}{c}0.007 \\
(0.006)\end{array}$ \\
\hline $\begin{array}{l}\text { Panel B: } 2 S L S \\
\text { Fr. Immigrant }\end{array}$ & $\begin{array}{c}-0.117^{* *} \\
(0.050)\end{array}$ & $\begin{array}{c}-0.008^{* *} \\
(0.004)\end{array}$ & $\begin{array}{l}-0.005 \\
(0.005)\end{array}$ & $\begin{array}{c}0.030^{* * *} \\
(0.006)\end{array}$ & $\begin{array}{c}0.033^{* * *} \\
(0.011)\end{array}$ & $\begin{array}{c}0.010 \\
(0.007)\end{array}$ \\
\hline F-stats & 251.3 & 251.3 & 251.3 & 251.3 & 251.3 & 251.3 \\
\hline Mean dep. var. & 0.038 & 0.005 & 0.007 & 0.006 & 0.018 & 0.014 \\
\hline $\begin{array}{l}\text { Natives/Immigrants } \\
\text { Ratio (1910) }\end{array}$ & 0.220 & 0.231 & 0.750 & 3.500 & 3.667 & 4.200 \\
\hline Obs. & 538 & 538 & 538 & 538 & 538 & 538 \\
\hline
\end{tabular}

Notes: this table presents results for a balanced panel of the 180 US cities with at least 30,000 residents in each Census year 1910, 1920, and 1930 (see Table A.2 in the appendix). The dependent variable is the fraction of native males in age range (20-35) working in the occupation reported at the top of each column. Panels A and B report, respectively, OLS and 2SLS results. Fr. Immigrants is the fraction of immigrants arrived in the previous decade over predicted city population, and is instrumented using the baseline version of the instrument constructed in Section 4.2 (see (2) in the main text). F-stat refers to the K-P F-stat for weak instrument. All regressions include city and state by year fixed effects. The mean of each dependent variable at baseline is shown at the bottom of the Table. Robust standard errors, clustered at the MSA level, in parenthesis. ${ }^{*} p<0.10,{ }^{* *} p<0.05,{ }^{* * *} p<0.01$ 
Table A.7: Immigration and Living Choices of Natives

\begin{tabular}{|c|c|c|c|c|}
\hline & (1) & (2) & (3) & (4) \\
\hline \multirow[t]{2}{*}{ Dep. Var. } & \multicolumn{2}{|c|}{$\begin{array}{l}\text { Share of children }<10 \\
\text { (native parents) }\end{array}$} & \multicolumn{2}{|c|}{$\begin{array}{c}\text { Share of families } \\
\text { (children }<10, \text { native parents) }\end{array}$} \\
\hline & Father employed & Father unskilled & Father employed & Father unskilled \\
\hline $\begin{array}{l}\text { Panel A: OLS } \\
\text { Fr. Immigrant }\end{array}$ & $\begin{array}{c}0.052 \\
(0.049)\end{array}$ & $\begin{array}{l}-0.027 \\
(0.075)\end{array}$ & $\begin{array}{c}0.032 \\
(0.045)\end{array}$ & $\begin{array}{l}-0.035 \\
(0.076)\end{array}$ \\
\hline $\begin{array}{l}\text { Panel B: } 2 S L S \\
\text { Fr. Immigrant }\end{array}$ & $\begin{array}{c}0.049 \\
(0.037)\end{array}$ & $\begin{array}{c}-0.138^{* *} \\
(0.061)\end{array}$ & $\begin{array}{c}0.024 \\
(0.034)\end{array}$ & $\begin{array}{l}-0.171^{* * *} \\
(0.063)\end{array}$ \\
\hline $\begin{array}{l}\text { F-stat } \\
\text { Mean dep. var. } \\
\text { Obs. }\end{array}$ & $\begin{array}{c}251.3 \\
0.908 \\
538\end{array}$ & $\begin{array}{c}251.3 \\
0.332 \\
538\end{array}$ & $\begin{array}{c}251.3 \\
0.901 \\
538\end{array}$ & $\begin{array}{c}251.3 \\
0.318 \\
538\end{array}$ \\
\hline
\end{tabular}

Notes: this Table presents results of OLS and 2SLS for a balanced panel of the 180 US cities with at least 30,000 residents in each Census year report. The dependent variable are described on the top part of the Table. Fr. Immigrants refers to the fraction of immigrants arrived in the previous decade over predicted city population, and is instrumented using the baseline version of the instrument constructed in Section 4.2. The mean of dependent variables is shown at the bottom of the Table. KP F-stat is the Kleibergen-Paap F stat for joint significance of instruments. All regressions include city and state by year fixed effects. Robust standard errors, clustered at the MSA level, in parenthesis. ${ }^{*} p<0.10,{ }^{* *} p<0.05,{ }^{* * *} p<0.01$ 
Table A.8: Immigration and Education of Native Children

Dep. Var.: Fraction attending school

Sons of natives

Daughters of natives
(1)
(2)
(3)
(4)
(5)
(6)

Age group: Age 6-14 Age 15-18 Age 19-24 Age 6-14 Age 15-18 Age 19-24

Panel A: OLS

Fr. Immigrant

$\begin{array}{cccccc}0.007 & -0.081 & 0.010 & -0.025 & 0.059 & -0.006 \\ (0.040) & (0.080) & (0.019) & (0.041) & (0.076) & (0.027)\end{array}$

\begin{tabular}{lcccccc} 
Panel B: 2SLS & & & & & & \\
Fr. Immigrant & $0.067^{* * *}$ & $-0.100^{* *}$ & 0.011 & 0.017 & 0.044 & $-0.042^{*}$ \\
& $(0.025)$ & $(0.049)$ & $(0.017)$ & $(0.027)$ & $(0.059)$ & $(0.023)$ \\
\hline Dep. var: & .933 & .241 & .015 & .936 & .22 & .013 \\
Obs. & 538 & 538 & 538 & 538 & 538 & 538 \\
\hline \hline
\end{tabular}

Notes: this Table presents results of OLS and 2SLS for a balanced panel of the 180 US cities with at least 30,000 residents in each Census year report. The dependent variable are described on the top part of the Table. Fr. Immigrants refers to the fraction of immigrants arrived in the previous decade over predicted city population, and is instrumented using the baseline version of the instrument constructed in Section 4.2. The mean of dependent variables is shown at the bottom of the Table. KP F-stat is the Kleibergen-Paap F stat for joint significance of instruments. All regressions include city and state by year fixed effects. Robust standard errors, clustered at the MSA level, in parenthesis. ${ }^{*} p<0.10,{ }^{* *} p<0.05,{ }^{* * *} p<0.01$ 
Table A.9: Immigration and Marriage Rates of Native Men aged 20-35 (2SLS results)

\begin{tabular}{|c|c|c|c|c|c|c|}
\hline & (1) & (2) & (3) & (4) & $(5)$ & (6) \\
\hline & \multicolumn{3}{|c|}{ All Native Men } & \multicolumn{3}{|c|}{ Second Generation Men } \\
\hline Wife & All & Native Parentage & Immigrant & All & Native Parentage & Immigrant \\
\hline \multicolumn{7}{|c|}{ Dependent Variable: Marriage rates } \\
\hline Fr. Immigrant & $\begin{array}{c}0.190^{* * *} \\
(0.054)\end{array}$ & $\begin{array}{c}0.296^{* * *} \\
(0.064)\end{array}$ & $\begin{array}{c}0.022 \\
(0.016)\end{array}$ & $\begin{array}{l}0.106^{*} \\
(0.063)\end{array}$ & $\begin{array}{c}0.215^{* * *} \\
(0.075)\end{array}$ & $\begin{array}{l}0.063^{*} \\
(0.036)\end{array}$ \\
\hline Mean dep. var. & 0.45 & 0.27 & 0.03 & 0.42 & 0.16 & 0.04 \\
\hline F-stat & 251.3 & 251.3 & 251.3 & 251.3 & 251.3 & 251.3 \\
\hline Obs. & 538 & 538 & 538 & 538 & 538 & 538 \\
\hline
\end{tabular}

Notes: this Table presents results of 2SLS for a balanced panel of the 180 US cities with at least 30,000 residents in each Census year report. In panel A, the dependent variable is the marriage rates of men aged 20-35 by husband parentage. In panel $\mathrm{B}$, the dependent variable is the children to women ratio by father parentage. We consider only children of women aged 18-33. For example, in column 2 of Panel B, the dependent variable is the number of children with native mother aged 18-33 and father with a native parentage over the number of native women aged 18-33. Columns 4-6 focus on women who are second generation immigrants. Fr. Immigrants refers to the fraction of immigrants arrived in the previous decade over predicted city population, and is instrumented using the baseline version of the instrument constructed in Section 4.2. The mean of dependent variables is shown at the bottom of the Table. KP F-stat is the Kleibergen-Paap F stat for joint significance of instruments. All regressions include city and state by year fixed effects. Robust standard errors, clustered at the MSA level, in parenthesis. ${ }^{*} p<0.10,{ }^{* *} p<0.05,{ }^{* * *} p<0.01$ 
Table A.10: Immigration and Marriage Rates of Natives by parentage (2SLS results)

Dep. Variable: Marriage rates

\begin{tabular}{|c|c|c|c|c|c|c|}
\hline \multirow{3}{*}{$\begin{array}{l}\text { Panel A: } \\
\text { Own Parents }\end{array}$} & (1) & (2) & (3) & (4) & (5) & (6) \\
\hline & \multicolumn{3}{|c|}{ Women Age 18-25 } & \multicolumn{3}{|c|}{ Women Age 26-33 } \\
\hline & Native & Mixed & Foreign & Native & Mixed & Foreign \\
\hline Fr. Immigrant & $\begin{array}{c}\overline{0.127^{* * *}} \\
(0.049)\end{array}$ & $\begin{array}{c}\overline{0.192^{* * *}} \\
(0.055)\end{array}$ & $\begin{array}{c}\overline{0.211^{* * *}} \\
(0.061)\end{array}$ & $\begin{array}{c}0.068 \\
(0.042)\end{array}$ & $\begin{array}{c}0.163 \\
(0.113)\end{array}$ & $\begin{array}{c}0.117 \\
(0.112)\end{array}$ \\
\hline $\begin{array}{l}\text { Mean Dep. Var. } \\
\text { Obs. }\end{array}$ & $\begin{array}{c}0.340 \\
538\end{array}$ & $\begin{array}{c}0.257 \\
538\end{array}$ & $\begin{array}{c}0.277 \\
538\end{array}$ & $\begin{array}{c}0.642 \\
538\end{array}$ & $\begin{array}{c}0.603 \\
538\end{array}$ & $\begin{array}{c}0.587 \\
538\end{array}$ \\
\hline Panel B: & \multicolumn{3}{|c|}{ Men Age 20-27 } & \multicolumn{3}{|c|}{ Men Age 28-35 } \\
\hline Own Parents & Native & Mixed & Foreign & Native & Mixed & Foreign \\
\hline Fr. Immigrant & $\begin{array}{l}0.139^{* *} \\
(0.059)\end{array}$ & $\begin{array}{c}0.227^{* * *} \\
(0.058)\end{array}$ & $\begin{array}{c}0.035 \\
(0.067)\end{array}$ & $\begin{array}{l}-0.029 \\
(0.075)\end{array}$ & $\begin{array}{c}0.013 \\
(0.091)\end{array}$ & $\begin{array}{c}0.047 \\
(0.078)\end{array}$ \\
\hline $\begin{array}{l}\text { Mean Dep. Var. } \\
\text { Obs. }\end{array}$ & $\begin{array}{c}0.297 \\
538\end{array}$ & $\begin{array}{c}0.210 \\
538\end{array}$ & $\begin{array}{c}0.233 \\
538\end{array}$ & $\begin{array}{c}0.623 \\
538\end{array}$ & $\begin{array}{c}0.575 \\
538\end{array}$ & $\begin{array}{c}0.561 \\
538\end{array}$ \\
\hline
\end{tabular}

Notes: this Table presents results of 2SLS for a balanced panel of the 180 US cities with at least 30,000 residents in each Census year report. The dependent variable is the marriage rates of the groups describled in each panel. Fr. Immigrants refers to the fraction of immigrants arrived in the previous decade over predicted city population, and is instrumented using the baseline version of the instrument constructed in Section 4.2. The mean of dependent variables is shown at the bottom of the Table. KP F-stat is the Kleibergen-Paap F stat for joint significance of instruments. All regressions include city and state by year fixed effects. Robust standard errors, clustered at the MSA level, in parenthesis. ${ }^{*} p<0.10,{ }^{* *} p<0.05,{ }^{* * *} p<0.01$ 
Table A.11: Immigration and LFP of Native Women - 2SLS results

Dep. Var.: LFP of Native Women

(1) (2) (3) (4) (5)

Age 18-33 Age 18-33 Age 18-25 Age 26-33 Age 34-65

\begin{tabular}{lccccc} 
& OLS & 2SLS & 2SLS & 2SLS & 2SLS \\
\hline Fr. Immigrant & -0.084 & $-0.115^{*}$ & $-0.135^{* *}$ & 0.023 & 0.042 \\
& $(0.083)$ & $(0.061)$ & $(0.067)$ & $(0.061)$ & $(0.041)$ \\
\hline F-stat & & 251.3 & 251.3 & 251.3 & 251.3 \\
Mean dep. var. & .42 & .42 & .49 & .33 & .25 \\
Obs. & 538 & 538 & 538 & 538 & 538 \\
\hline \hline
\end{tabular}

Notes: this Table presents results of OLS and 2SLS for a balanced panel of the 180 US cities with at least 30,000 residents in each Census year report. The dependent variable is the labor force participation of women in the different age range. $F r$. Immigrants refers to the fraction of immigrants arrived in the previous decade over predicted city population, and is instrumented using the baseline version of the instrument constructed in Section 4.2. The mean of dependent variables is shown at the bottom of the Table. KP F-stat is the Kleibergen-Paap F stat for joint significance of instruments. All regressions include city and state by year fixed effects. Robust standard errors, clustered at the MSA level, in parenthesis. ${ }^{*} p<0.10$, ${ }^{* *}$ $p<0.05,{ }^{* * *} p<0.01$ 


\section{B Graphical Example}

As discussed in the main text, the shift-share instrument exploits two sources of variation: first, cross-sectional variation in the share of individuals from each ethnic group living in different US cities in 1900; second, time-series variation due to changes in the total number of immigrants from any sending region entering the United States in a given decade. To illustrate how the two sources of variation are combined by our instrument, Figure B.1 presents a simple example for two ethnic groups (Germans and Italians) and three cities (Chicago, Milwaukee, and San Francisco).

German immigration fell between 1910 and 1920 due to WWI, but rebounded after 1920, as the quotas were quite generous with respect to Germany. Instead, between 1910 and 1930, Italian immigration declined monotonically. Starting from Panel A, Chicago had large Italian and German communities in 1900. In line with the aggregate flows, both the actual (straight lines) and the predicted (dotted lines) number of Italians (yellow lines) and Germans (blue lines) arriving in Chicago fell between 1910 and 1920. However, after 1920, while Italian immigration continued its decline, Chicago experienced a positive immigration shock from Germany.

Next, Panel B presents the example of Milwaukee, a city with a relatively large German community, but with almost no Italians in 1900. As a result, for this city, variation in immigration was driven by changes in German, and not Italian, immigration. Finally, while very few Germans were living in San Francisco in 1900, Italian settlements were fairly large in this city. As documented in Panel C, the actual and predicted immigration shock for San Francisco was due to the decline in Italian immigration, and only marginally to the inflow of Germans after 1920.

The instrument in equation (2) extends this example to many cities and many ethnic groups, but the logic behind it can be grasped by looking at the patterns in Panels A to C of Figure B.1 
Figure B.1: Actual and Predicted Immigration
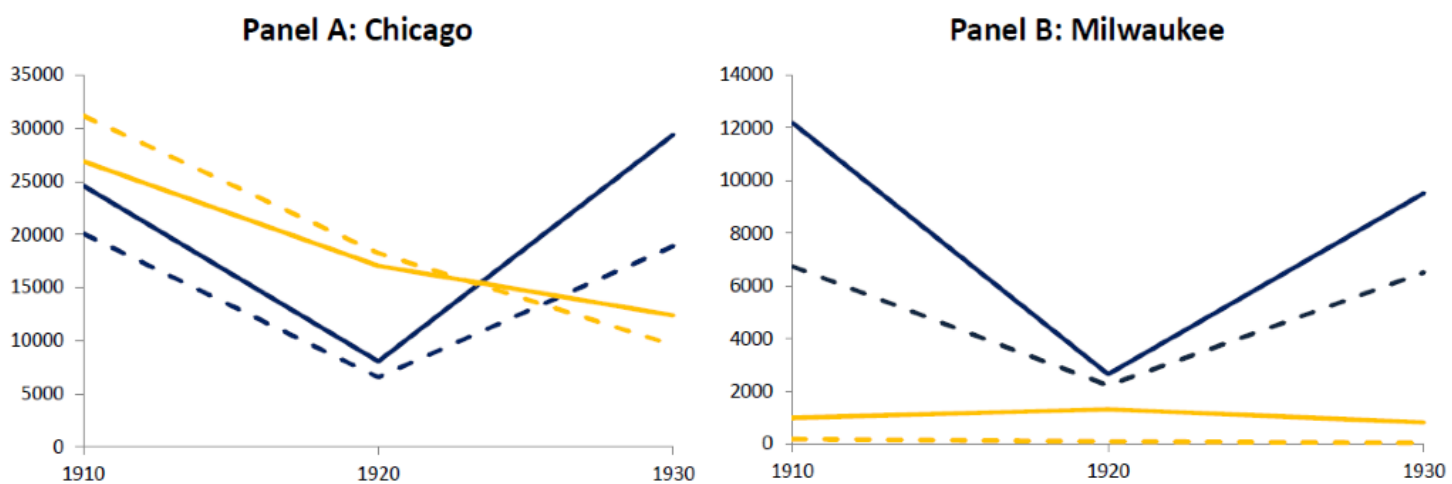

Panel C: San Francisco

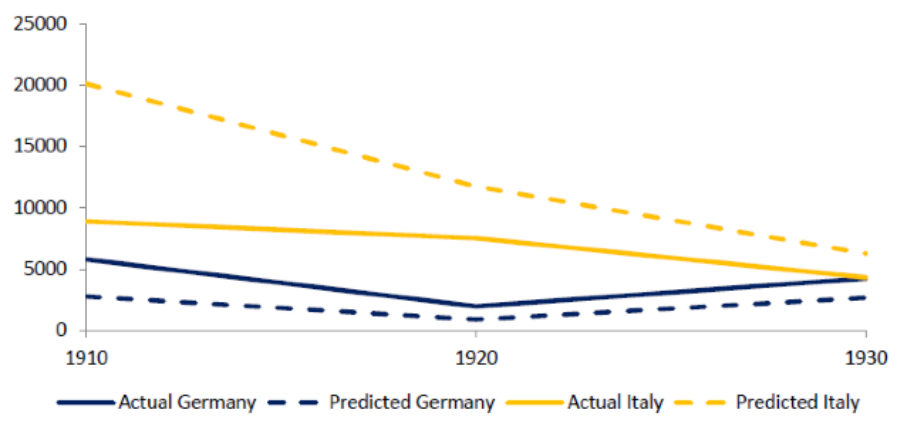

Notes: This Figure reports the actual and predicted number of Italians and Germans arrived during the previous decade to Chicago (Panel A), Milwaukee (Panel B), and San Francisco (Panel C), in 1910, 1920, and 1930. Predicted immigration is obtained from the instrument constructed in equation (2) in the main text. Source: from IPUMS sample of US Census (Ruggles et al., 2015). 


\section{References}

Ruggles, S., K. Genadek, R. Goeken, J. Grover, and M. Sobek (2015). Integrated public use microdata series: Version 6.0 [dataset]. Minneapolis: University of Minnesota. 